\title{
On the evidence for human use and control of fire at Schöningen
}

Mareike C. Stahlschmidt ${ }^{\mathrm{a}}$, Christopher E. Miller ${ }^{\mathrm{a}, \mathrm{b}}$, Bertrand Ligouis ${ }^{\mathrm{c}}$, Ulrich Hambach ${ }^{\mathrm{d}}$, Paul

Goldberg $^{\text {a, e }}$, Francesco Berna ${ }^{\text {e, f }}$, Daniel Richter ${ }^{\text {d, g }}$, Brigitte Urban ${ }^{\text {h, i, }}$, Jordi Serangeli ${ }^{\text {i }}$, Nicholas J. Conard $^{\mathrm{a}, \mathrm{b}, \mathrm{i}}$



${ }^{\mathrm{b}}$ Senckenberg Centre for Human Evolution and Palaeoenvironment, University of Tübingen, 72070, Tübingen, Germany

${ }^{\mathrm{c}}$ Laboratories for Applied Organic Petrology (LAOP), Institute for Archaeological Sciences, University of Tübingen, 72070 Tübingen, Germany

${ }^{\mathrm{d}}$ BayCEER \& Lehrstuhl für Geomorphologie, Universität Bayreuth, Universitätsstraße 30, 95440 Bayreuth, Germany

${ }^{\mathrm{e}}$ Department of Archaeology, Boston University, 675 Commonwealth Avenue, Boston, MA 02215, USA

${ }^{\mathrm{f}}$ Department of Archaeology, Simon Fraser University, 8888 University Drive, Burnaby, British Columbia, Canada, V5A 1S6

${ }^{\mathrm{g}}$ Department of Human Evolution, Max Planck Institute for Evolutionary Anthropology

Deutscher Platz 6, 04103 Leipzig, Germany

${ }^{\mathrm{h}}$ Leuphana University Lüneburg, 21335 Lüneburg, Germany

${ }^{\mathrm{i}}$ Early Prehistory and Quaternary Ecology, Institute for Pre- and Protohistory and Archaeology of the Middle Ages, University of Tübingen, 72070 Tübingen, Germany

* Corresponding author.

E-mail address: mareike.stahlschmidt@uni-tuebingen.de

Keywords: Early fire; Northern latitudes; Human behavior; Paleolithic archaeology; Micromorphology 


\begin{abstract}
When and how humans began to control fire has been a central debate in Paleolithic archaeology for decades. Fire plays an important role in technology, social organization, subsistence, and manipulation of the environment and is widely seen as a necessary adaptation for the colonization of northern latitudes. Many researchers view purported hearths, burnt wooden implements, and heated flints from Schöningen as providing the best evidence for the control of fire in the Lower Paleolithic of Northern Europe. Here we present results of a multianalytical study of the purported hearths along with a critical examination of other possible evidence of human use or control of fire at Schöningen. We conclude that the analyzed features and artifacts present no convincing evidence for human use or control of fire. Our study also shows that a multianalytical, micromorphological approach is the best methodology for evaluating claims of early evidence of human-controlled fire. We advise caution with macroscopic, qualitative identification of combustion features, burnt flint, and burnt wood without the application of such techniques as micromorphology, Fourier transform infrared (FTIR) spectroscopy, organic petrology, luminescence, and analysis of mineral magnetic parameters. The lack of evidence for the human control of fire at Schöningen raises the possibility that fire control was not a necessary adaptation for the human settlement of northern latitudes in the Lower Paleolithic.
\end{abstract}




\section{Introduction}

The origins of the use and control of fire is one of the central and most debated topics in Paleolithic archaeology and human evolution (e.g., Goudsblom, 1986; James et al., 1989; de Lumley, 2006; Gowlett, 2006; Wrangham, 2009; Alperson-Afil and Goren-Inbar, 2010; Roebroeks and Villa, 2011a; Sandgathe et al., 2011a; Gowlett and Wrangham, 2013). Fire use and control would have provided several crucial advantages to early humans: it can serve as a light and heating source (Oakley, 1955; Bellomo, 1994; Gilligan, 2010), as a hunting aid (Goudsblom, 1986; Mallol et al., 2007), can be used for cleaning occupation surfaces (Goldberg et al., 2009, Wadley et al., 2011), as protection from predators (Goudsblom, 1986; Brain, 1991), as a means to improve tool technology (Ahlers, 1983; Brown et al., 2009; Mallol et al., 2007), and as a way to increase food range, its nutritional value, and preservation (Stahl et al., 1984; Bellomo, 1994; Wrangham et al., 1999; Wrangham and Conklin-Brittain, 2003; Mallol et al., 2007; Wrangham, 2009; for an overview, see Clark and Harris, 1985). Because of these advantages, archaeologists assign fire use and control an important role in human evolution. Brain (1991) suggests that fire use and control could have increased early humans' competiveness (Brain, 1991), and Gowlett (2006) and Wrangham (2009) amongst others (Rolland, 2004; Pruetz and LaDuke, 2010) suggest that fire use and control impacted the evolution of biological traits, including brain size and cognition.

Furthermore, several researchers see the use and control of fire as a precondition for the first settlement of northern latitudes (Oakley, 1955; Brace et al., 1987; Straus, 1989; Weiner et al., 1998; Wrangham et al., 1999; Klein, 2002; Rolland, 2004; Gowlett, 2006; Preece et al., 2006). The sites at Schöningen are referenced as among the earliest such examples (Thieme, 1997, 2005, 2007a, b, c, d; Mania, 1995; Klein, 2002, 2009; Goren-Inbar et al., 2004; Alperson-Afil and Goren-Inbar, 2006; Gowlett, 2006; Preece et al., 2006; Berna and Goldberg, 2008; Wrangham, 2009; Daniau et al., 2010; Roebroeks and Villa, 2011a; Gowlett and Wrangham, 2013; Shahack-Gross et al., 2014). Northern latitudes present several challenges to their occupants, having shorter duration of daylight in winter, severely cold winters, a variety of large predators, and a scarcity of edible plants during winter, 
consequently demanding a stronger reliance on animal resources. According to Gilligan (2010) these challenges can be answered through seasonal migration, physical adaptation, or technological improvement in the form of new hunting weaponry, clothing, use of shelters, and use of fire.

Most evidence for early use of fire relies on macroscopic, qualitative identification of residues and objects that appear to have been affected by fire, often described as a change in color (e.g., Purdy, 1971, 1975; Purdy and Brooks, 1971; Shipman et al., 1984). However, macroscopic observations of burning are often misleading and need to be confirmed by specific analyses, such as micromorphology, FTIR, organic petrology, analysis of mineral magnetic parameters, and thermoluminescence measurements (e.g., James et al., 1989; Stiner et al., 1995; Shahack-Gross et al., 1997; Richter, 1998; Goldberg, et al., 2001; Ligouis, 2006; Hanson and Cain, 2007; Roebroeks and Villa, 2011a). In short, human control of fire is best investigated by employing a micromorphological approach (e.g., Karkanas et al., 2007).

Several researchers cite hearths, burnt wood, and flint from different localities and find horizons as providing evidence for human use and control of fire at Schöningen (e.g., Klein, 2002; Alperson-Afil and Goren-Inbar, 2006; Berna and Goldberg, 2008; Wrangham, 2009; Weiner, 2010; Roebroeks and Villa, 2011a). However, apart from a preliminary and inconclusive micromorphological investigation of one of the purported hearths (Schiegl and Thieme, 2007), only macroscopic, qualitative observations of fire use and control have been reported at Schöningen (Thieme, 1997, 1999, 2005, 2007b; Schiegl and Thieme, 2007). Here we present the first contextualized, multianalytical study of deposits, materials, and purported hearths at Schöningen and show that claims for human use and control of fire are highly dubious.

Early evidence for human use of fire

Evidence for fire in the archaeological record can be the result of either human action or natural fire, and it is commonly difficult to separate the two. Therefore, the burden of proof rests on the archaeologists to demonstrate that the evidence for fire clearly represents human action, and not a 
natural process. Identification of human use of fire is further complicated by the possible human exploitation of natural fire. Archaeologists generally differentiate three stages of anthropogenic fire: (1) the use, (2) control, and (3) production of fire (e.g., Frazer, 1930; Pruetz and LaDuke, 2010; Sandgathe et al., 2011a). Roebroeks and Villa (2011a) and Sandgathe et al. (2011a, b) further differentiate between observations of sporadic fire use - including the use and controlled use of fire from natural, more unreliable sources - and habitual fire use, which infers the production of fire, in the archaeological record (see also Shahack-Gross et al., 2014). In many cases, the stages of fire use can be differentiated from each other and from natural fire by a contextual analysis (e.g., Bellomo, 1994; Weiner et al., 1998; Goldberg et al., 2001; Gowlett et al., 2005; Karkanas et al., 2007; Roebroeks and Villa, 2011a; Berna et al., 2012; Shahack-Gross et al., 2014).

Natural fire The earliest evidence for naturally occurring fire are fragments of charcoal found in rocks dating to the Devonian (Scott, 2000). Fires can be caused by lightning strikes (which are the source for the majority of natural fires), volcanic activity, sparks from rock falls, spontaneous combustion, and meteorite impacts (Batchelder, 1967; Tutin et al., 1996; Jones and Lim, 2000; Scott, 2000). Treecrown fires, volcanic eruptions, and lightning strikes can produce temperatures over $700^{\circ} \mathrm{C}$, and tree stumps, burning humus, or peat fires can burn over elongated periods (Davis, 1959; Stach et al., 1975; Isaac, 1982; James et al., 1989; Scott, 1989, 2000; Pyne et al., 1996; DeBano et al., 1998; Buenger, 2003; Christian et al., 2003; Fessler, 2006). Lightning strikes and burning tree stumps can produce local heat-alterations of sediments that mimic anthropogenic combustion features (see also Isaac, 1982; Clark and Harris, 1985; Isaac and Harris, 1997; Scott, 2000).

Evidence that archaeologists assume to be indicative of anthropogenic fire — such as burnt bone or heated flint or sediment—can also be produced naturally. For example, Hendey (1976) reported Miocene burnt bone from the fossil bone bed of Langebaanweg, whereas Avery et al. (2004) mention burnt tortoise bones caused by bush fires in South Africa; Bordes (1957) reported Miocene burnt flint from Thenay, France. Clark et al. (1984) and Clark and Harris (1985) reported Pliocene burnt sediment at Middle Awash, Ethiopia. 
Human use of fire Human use or opportunistic use (Clark and Harris, 1985) of fire includes both conceptualization of fire and its collection from natural sources (Pruetz and LaDuke, 2010). Fire use does not represent a unique human behavior, since chimpanzees have been observed to show predictive behavior towards fire, and other species are known to exploit wild fires for warmth and food (Goudsblom, 1986; Wrangham, 2009; Pruetz and LaDuke, 2010). Human knowledge of fire is difficult to identify in the archaeological record, and most hypotheses regarding early human-fire interaction are based on inferences or indirect data (e.g., Berna et al., 2012; Gowlett and Wrangham, 2013). Some of the earliest evidence for knowledge of fire comes from the ca. 1.0 Ma site of Wonderwerk in South Africa. Here, Berna et al. (2012) described ash remains and burnt bone, as identified by micromorphological and FTIR analysis, inside the cave, arguing that one would not expect natural fire in this setting. Gowlett and Wrangham (2013), using observations of changes in human morphology, argue that humans used fire as early as $1.5 \mathrm{Ma}$, despite the lack of direct archaeological evidence.

Human control of fire Control of fire or predetermined use (Clark and Harris, 1985) means the maintenance of a fire via fuel provisioning and restraint. The control of fire includes preservation and transport of fire from natural sources of ignition and represents a much more complex and unique human behavior, excluding some rehabilitated chimpanzees who are capable of managing campfires (Brewer, 1978). Researchers have argued for indirect evidence for the control of fire, such as selective burning of materials (Gowlett and Wrangham, 2013) and materials heated to high temperatures at archaeological sites (e.g., Brain and Sillen, 1988; Bellomo, 1993, 1994; Preece et al., 2006; Backhouse and Johnson, 2007). The latter arguments assume that high temperatures are only reached within campfires and are not reached by natural fires, which exhibit a shorter burning time; however, this assumption is questionable (see above and Gowlett and Wrangham, 2013).

Combustion features, in the form of structured hearths, provide the most direct evidence for human control of fire; however, they can be difficult to identify since they are often ephemeral features subject to post-depositional alteration. Micromorphological analysis has proven useful in the analysis of archaeological combustion features (Courty et al., 1989; Goldberg et al., 2001; Karkanas et 
al., 2007; Wadley et al., 2011; Mentzer, 2012; Shahack-Gross et al., 2014). Localized features consisting of heat-altered sediments that excavators interpreted as the remains of hearths have been reported and subsequently criticized at the Lower Paleolithic sites of Chesowanja (Gowlett et al., 1981, 1982; Isaac, 1982), Gadeb (Clark and Kurashina, 1979; Barbetti, 1986), Koobi Fora (Isaac, 1984; Clark and Harris, 1985; Barbetti, 1986), and Olorgesailie (Isaac, 1977, 1984) in Africa, and Zhoukoudian (Wu, 1985; Binford et al., 1985; Weiner et al., 1998; Goldberg, et al., 2001) in Asia (for a critical overview see James et al., 1989). Alperson-Afil (2008) and Alperson-Afil et al. (2006, 2007) proposed indirect evidence of hearths at Gesher Benot Ya'aqov, dated to 800,000 BP. They inferred the former presence of hearths using spatial analysis of burnt flint, as verified by thermoluminescence analysis. However, in their discussion of burning by natural fire they only refute the possibility of an in situ natural fire. Similarly, they do not discuss the possibility that nodules of raw material had been heat altered before human use.

In Europe, burnt sediment at the Lower Paleolithic sites of Vértesszöllös (Vértes and Dobosi, 1990) Menez-Dregan (Monnier et al., 1994, 2001), and Terra Amata (Villa, 1982, 1983), an accumulation of purported burnt wood at Bilzingsleben (Mania, 1991; Mania and Mania, 2000; but see Steguweit, 2003), and hearths at Schöningen (Thieme 1997, 2005) have been reported as evidence of human control of fire. However, the researchers at these sites do not demonstrate that the purported heat-altered materials are anthropogenic (see also James et al., 1989; Roebroeks and Villa, 2011a), and the dating of Menez-Dregan is still unclear (Mercier et al., 2004). Gowlett (2006) and Preece et al. (2007) reported on scatters of burnt flint and bone next to possible hearths at Beeches Pit, UK. To date, no data have been published to demonstrate that the supposed hearths were formed through heating, and it is not clear if the heated bones and lithic artifacts were produced by human activities or natural fires (see also Preece et al., 2007).

The most direct and unambiguous evidence for the control of fire and of habitual fire use in the form of hearths and reused hearths comes from Qesem Cave in Israel, dated to 400,000 and 300,000 BP, respectively (Karkanas et al., 2007; Shahack-Gross et al., 2014). In the Middle Paleolithic and Middle Stone Age, evidence for control of fire with discrete hearths is known in Africa from 
Sibudu (Wadley et al., 2011), in Asia from sites such as Tabun, Kebara, and Hayonim (Goldberg, 2003), and in Europe from sites such as Pech-de-l'Azé, Roc de Marsal (Goldberg, 2004; Goldberg et al., 2012; Aldeias et al., 2012), and Abric Romani (Vallverdú et al., 2010).

Human production of fire Fire can be artificially produced by wood-on-wood friction or stone-onstone percussion in addition to a tinder source (Hough, 1926; Weiner, 2003). Direct evidence for this behavior is rare and so far has only been reported from the Upper Paleolithic (e.g., Weiner and Floss, 2005; Sorensen et al., 2014), with one possible exception from the Middle Paleolithic site of Bettencourt, France (Rots, 2011, in press). Habitual fire use, manifested in the archaeological record as a repetitive pattern of fire control, is often seen as a prelude to the production of fire (Frazer, 1930; Goudsblom, 1986, Gowlett, 2006; Pruetz and LaDuke, 2010). Sandgathe et al. (2011a, b) maintain that habitual fire use presents indirect evidence for fire production. They further argue, based on a lack of evidence for habitual fire use at the sites of Roc de Marsal and Pech-de-l'Azé, that Middle Paleolithic humans in Europe still relied on scarce, natural sources of ignition and that Neanderthals lacked the ability to make fire (Sandgathe et al., 2011a; but see Roebroeks and Villa, 2011b).

\section{Schöningen}


Mountains to the southeast (Fig. 1) and is situated at the southeastern foot of the Elm, a limestone ridge $25 \mathrm{~km}$ long and up to $8 \mathrm{~km}$ wide (Elsner, 2003) at an altitude of $114 \mathrm{~m}$ above mean sea level.

Schöningen is located on the southwestern syncline of the Offleben salt wall and in the Helmstedt Staßfurt salt structure (Mania, 1995; Brandes et al., 2012). Today the site complex of Schöningen is located in an open-cast lignite mine, which exposes Middle Pleistocene sites sandwiched between glaciogenic deposits of the Elsterian and Saalian glaciations (Urban, 1991a; Mania, 1995; Elsner, 2003; Ehlers et al., 2004). The Paleolithic site complex of Schöningen is preserved in an elongated trough, which dissects the underlying Paleogene marine bedrock. Lang et al. $(2012,2015)$ recently interpreted the trough as a tunnel valley that formed underneath the Elsterian ice 
shield. Mania $(1995,2007)$ interpreted the formation of the trough as a result of salt dome solution, which resulted in lowering of the basin. He suggested that recurring fluvial activity at the onset of a warm period would have eroded and infilled the trough during the interglacial following the Elsterian. Stratigraphy The trough is filled with Elsterian glaciogenic deposits that are unconformably overlain by a sequence of interglacial deltaic and lacustrine deposits. These deposits are in turn capped by Saalian glaciogenic deposits and Weichselian loess (Fig. 2). The interglacial Middle Pleistocene sedimentary sequence, which contains the numerous Paleolithic layers, consists of three major superimposed deltaic systems (Urban, 1995, 2007; Lang et al., 2012; Figs. 2 and 3). Urban (2007) and van Kolfschoten (2014) assign the first deltaic systems to the Holsteinian interglacial and MIS 11. However, the correlation of the Holsteinian interglacial with MIS 9 or 11 is still under debate (Geyh and Müller, 2005; Ashton et al., 2008; Geyh and Krbetschek, 2012).

The second major deltaic system consists of a series of lacustrine deposits (Figs. 2 and 3; Lang et al., 2012) and contains the materials from sites Schöningen 12 B and Schöningen 13 II analysed in this study. Biostratigraphic evidence places Schöningen 13 II and 12 B in the Reinsdorf Interglacial, which was most recently dated to MIS 9 (Urban, 2007; Urban and Sierralta, 2012; but see Urban et al., 2015). Some researchers (Litt et al., 2007; Bittmann, 2012; Lang et al., 2012) argue that the Reinsdorf Interglacial is a possible equivalent subset of the Holsteinian Interglacial. The sedimentary sequence at Schöningen 13 II consists of five lacustrine cycles of grey calcareous mud that grade upward into dark brown organic muds (Thieme, 2007c; Urban, 2007; Stahlschmidt et al., 2015). Geological studies (Mania, 2007; Urban, 2007; Lang et al., 2012) interpret the alternation between marl and organic mud at Schöningen 13 II as a result of lake-level fluctuations related to variations in climate. Similarly, the sedimentary sequence at Schöningen 12 B consists of sequences of calcareous muds and organic rich deposits interpreted as the result of lake level changes (Thieme and Maier, 1995).

Urban et al. (1991a) assign the third episode of deltaic infill, which has only been exposed in the northern mine, to the Schöningen Interglacial, which they interpret as an equivalent of marine isotope stage 7 (MIS 7). The same authors (Urban et al., 1991a, b) also report travertine and peat in the northern part of the mine, which they correlate with Eemian MIS 5e and substages $5 \mathrm{~d}$ and $5 \mathrm{c}$. 
Archaeology During the course of mining, which began at Schöningen in the 1970s, the miners artificially lowered the groundwater table through the construction of several deep wells. Starting in 1983 state archaeologist $\mathrm{H}$. Thieme monitored operations at the lignite mine and discovered the first Paleolithic artifacts in 1992 (Thieme, 1997). Additional wells were then constructed to facilitate subsequent archaeological excavation. Twenty-eight Paleolithic sites and find horizons were discovered in association with the mine (Serangeli et al., 2012, Serangeli and Conard, 2015), most of which were excavated as salvage operations. The sites contain lithic material, bone remains, and wooden artifacts, the last being excellently preserved due to the waterlogged state of the deposits. The materials discussed in this study come from Schöningen 12 B and 13 II.


artifacts at Schöningen 13 II-4 are mostly found at the contact of layer 4b/c, a calcareous marl, with layer 4b, an organic mud (e.g., Stahlschmidt et al., 2015), and consist of butchered horse remains, wooden spears, and numerous flint artifacts in addition to purported evidence for anthropogenic fire (Thieme, 1997, 2005, 2007b; Voormolen, 2008; Serangeli and Böhner, 2012; van Kolfschoten, 2014; Schoch et al., 2015; Fig. 4).

At Schöningen 13 II-3 and 13 II-2 bone remains, lithic artifacts, and one wooden artifact were discovered (Thieme, 2002, 2007d; Serangeli et al., 2012a). Here, the recent excavation team observed an additional case of possible heat-altered sediment. They noted a vertical crack several meters long through the calcareous marl of 13 II-3 and across layers 13 II-2 that was filled with black sediment (Fig. 5; see below).

Schöningen 12 B Schöningen 12 B was a rescue excavation, and the locality contains two find horizons. Find horizon 1 consists of a sandy mud and find horizon 2 of coarse detrital mud, both containing bone remains and lithic material (Thieme and Maier, 1995). Mania (1995) and Thieme (2007c) reported an accumulation of burnt wood in find horizon 2 and interpreted this accumulation of burnt wood as a possible hearth. The find horizon contained an additional fragment of supposedly burnt wood, the so-called Fackelkopf (ID 13325; see below). 
Evidence for fire Thieme (1997, 1999, 2002, 2005, 2007a, b) and Mania (1995) reported evidence for anthropogenic fire from six sites and find horizons at Schöningen (Table 1). Most of the evidence was based on qualitative, macroscopic observations; however, Richter $(1998,2007)$ conducted a thermoluminescence study of burnt flint pieces from Schöningen 13 I, and Schiegl and Thieme (2007) conducted an inconclusive micromorphological study of hearth 1 from Schöningen 13 II-4. Most of the arguments for the anthropogenic origin of fire at Schöningen are based on the association of supposedly burnt materials with archaeological remains (e.g., Thieme 2005).

Evidence for fire - hearths Thieme $(1997,1999,2005,2007 \mathrm{~b})$ interpreted four features at Schöningen as hearths (see Fig. 4). His interpretation was based on macroscopic observations of localized reddening of the calcareous marl, layer $4 \mathrm{~b} / \mathrm{c}$, at the contact with the organic mud, layer $4 \mathrm{~b}$, and on cracks in the sediment at this contact (Thieme, 1997, 1999, 2005, Schiegl and Thieme, 2007; Fig. 6). Thieme excavated the features only partially and preserved the remaining sediment columns in wooden cases for future analysis. The recent excavation team reopened and excavated the hearth features between 2010 and 2012, noting that they had been affected by bioturbation and drying (Fig. 6). No charcoal, burnt bone, or ash was recovered from the features. Thieme reported that the hearths had a dimension of $1 \mathrm{~m}^{2}$, whereas upon reopening the wooden cases, the reddened area was up to $3 \mathrm{~m}^{2}$, thus presenting what would be unusually large hearths (but see Shahack-Gross et al. [2014] for similarly large hearths). Preliminary micromorphological analysis by S. Schiegl on thin sections from hearth 1 detected the presence of quartz grains with surface cracks, which she suggested could have been caused by heating. However, Schiegl and Thieme (2007) also pointed out that the mollusk shells within the sediment from hearth 1 did not appear altered by heat. The authors reported these results as inconclusive (Schiegl and Thieme, 2007).

Evidence for fire - burnt wood Excavators have described fragments of burnt wood from Schöningen 13 II-1, 13 II-2 Berm, 13 II-4, 12 A find horizon 2, and 12 B (Mania, 1995; Thieme and Maier, 1995; Thieme, 1997, 1999, 2002, 2005, 2007a, b, c, d; pers. comm. W. Schoch; Table 1). Two accumulations of burnt wood in Schöningen 13 II-2 Berm and 12 A find horizon 2 were reported as 
hearths, but no details were provided. Thieme (2005) also reported a piece of wood that appeared to be worked by humans and also possibly burnt. He interpreted this as a roasting stick, or Bratspieß. Evidence for fire - burnt flint Richter (1998, 2007), Richter and Thieme (2012), and Richter and Krbetschek (in press) reported 13 burnt pieces of flint from Schöningen 13 I, which was confirmed with thermoluminescence and recently dated to $321 \pm 16 \mathrm{ka}$ (Richter and Krbetscheck, in press). None of these pieces show clear characteristics of having been worked or modified by humans (Richter, 1998, 2007; Richter and Thieme, 2012; Richter and Krbetscheck, in press).

Since its discovery and the reporting of evidence for fire, Schöningen has been cited in almost all of the major reviews of early evidence for fire (Gowlett, 2006; Klein, 2009; Wrangham, 2009; Alperson-Afil and Goren-Inbar, 2010; Daniau et al., 2010; Roebroeks and Villa, 2011a; Gowlett and Wrangham, 2013). Several studies mention fire-hardening of the wooden spears from Schöningen as evidence for human use of fire (Rice, 2007; Berna and Goldberg, 2008; Coolidge and Wynn, 2009; Alperson-Afil and Goren-Inbar, 2010; Weiner, 2010). Neither Thieme (1997, 2005) nor any subsequent studies (Schoch et al., 2015) described the spears as exhibiting evidence for heating.

\section{Material and methods}

\section{Materials}

Table 2 contains an overview of all samples and the performed analyses.

Hearths All four purported hearths from Schöningen 13 II-4 were sampled in blocks from various locations that encompass the sediments of layer $4 \mathrm{~b} / \mathrm{c}$, layer $4 \mathrm{~b}$, and their contact, where the purported hearths are located (Fig. 6). Hearth 1 was analyzed by all methods, whereas the remaining hearths were investigated only with micromorphology. One bulk sample from layer $4 \mathrm{~b}$, two block samples and one bulk sample from layer $4 \mathrm{~b} / \mathrm{c}$, and one block sample encompassing the contact of layer $4 \mathrm{~b} / \mathrm{c}$ with the overlying sediments, layer $4 \mathrm{~b}$, with no reddening in between, were additionally taken outside the hearths to serve as control samples (Table 2). The control bulk samples were used for a heating 
experiment, studied by micromorphology, FTIR, mineral magnetic parameters, and thermoluminescence, and the control block samples were studied by micromorphology and thermoluminescence.

Burnt sediment Two bulk samples from the black, purportedly burnt sediment from the crack running through Schöningen 13 II-3 and 13 II-2 were taken at the contact of an organic mud from 13 II-2 and studied by organic petrology.

Burnt wood A piece $\left(2 \mathrm{~mm}^{3}\right)$ of purported carbonized wood from a supposed wooden artifact from Schöningen 12 B and the attached sediment were studied by organic petrology. Sampling here was conducted by the Department of State Heritage Lower Saxony.

\section{Methods}

Both micromorphological and organic petrology analyses were employed to describe microscopic organic constituents. For clarity and consistency between the two methods we employ the term "plant tissue" for organic constituents originating from plants. This term is similar to soil micromorphology terms such as "plant residue" (Stoops, 2003) and organic petrology terms such as "macerals" (Taylor et al., 1998).

Micromorphology Micromorphology is the study of intact blocks of sediment and soils in thin section using a petrographic microscope. It permits identification of the composition, texture, structure, and fabric of the deposits, as well as the observation of pedogenic and anthropogenic features. Since the original integrity of the sediment is conserved it is possible to determine the relative spatial and temporal relationships among materials and voids in the sample (e.g., Courty et al., 1989). The technique of micromorphology has proven to be a powerful tool for detecting early fire by revealing the presence of ash and the in situ character of hearth-related features (e.g., at Sibudu [Goldberg et al., 2009], Qesem Cave [Karkanas et al., 2007; Shahack-Gross et al., 2014], Wonderwerk Cave [Berna et al., 2012], Kebara, and Hayonim Cave [Goldberg and Bar-Yosef, 1998]); it was also successfully applied to the correction of claims of fire at Zhoukoudian (Goldberg et al., 2001). 
For the micromorphological study, oriented blocks of sediment were collected in the field and stabilized by plaster of Paris or wooden containers. Sample preparation was conducted at the Geoarchaeology Laboratory, University of Tübingen. Samples were oven dried at $40^{\circ} \mathrm{C}$ for 1 day and then impregnated under a vacuum with a 7:3 part mixture of unpromoted polyester resin and styrene, catalyzed with methyl ethyl ketone peroxide (MEKP). After 5-10 days the samples were again heated at $50^{\circ} \mathrm{C}$ until they had hardened completely. The hardened blocks were then sliced into tiles of 50x75x10 mm. Thin sections were produced by Spectrum Petrographics, Inc. in Vancouver, Washington, U.S.A., and Th. Beckmann, Braunschweig, Germany. Analysis of the resulting thin sections was conducted with a Zeiss Axio Imager petrographic microscope under plane-polarized (PPL), cross-polarized (XPL), and blue light fluorescence, at magnifications of 20x to 500x.

Description and analysis follows Courty et al. (1989), Stoops (2003), and Stoops et al. (2010).

Organic petrology Organic petrology is a branch of earth sciences that is widely used in the study of peat, brown coal, and hard coal properties with reflected light microscopy (Taylor et al., 1998). The study of the reflectance and fluorescence of organic constituents can be informative about the presence of charred plant material (wood, seeds, tissues etc.), which constitutes important evidence for fuel use and combustion conditions (e.g., Schiegl et al., 2004; Ligouis, 2006; Goldberg et al., 2009; Clark and Ligouis, 2010).

Organic petrological investigations are carried out on well-polished surfaces of particulate- or block-samples in reflected white light and in fluorescence mode on organic particles known as "macerals" (see Stahlschmidt et al., 2015:Table 3 for organic petrology terms). Sample preparation for organic petrology was conducted at the Laboratory for Applied Organic Petrology (LAOP) at the University of Tübingen. Polarized light is used to assess the properties (anisotropy, mosaic structure) of the carbon forms, especially if they result from coal carbonization (coke) and from incomplete combustion of fossil fuels (nonburnt carbon in the form of char; Taylor et al., 1998). Analysis was conducted with a Leitz DMRX-MPVSP microscope photometer equipped for reflected white-light and blue-light illumination, and is set up with oil immersion objectives (20x to 50x). 
FTIR Fourier-Transform Infrared Spectrometric analysis was performed on thin sections and loose samples. Fourier-Transform Infrared (FTIR) spectroscopy is used in order to determine the characteristic molecular absorptions of infrared radiation by organic and inorganic material. The resulting infrared absorbance spectra are used to understand the composition of archaeological sediments and materials. Furthermore, FTIR spectroscopy is very sensitive to variations in composition (substitutions) and crystallography (atomic order) that result from diagenetic processes such as heat alteration (e.g., Weiner, 2010).

Sample preparation was performed at the MicroStratigraphy Laboratory at Boston University. Powdered aliquots of experimental and archaeological samples were analyzed by FTIR spectroscopy using a Thermo-Nicolet Nexus 470 IR spectrometer. Representative FTIR spectra were obtained by grinding a few tens of micrograms of sample with an agate mortar and pestle. About $0.1 \mathrm{mg}$ or less of the sample was mixed with about $80 \mathrm{mg}$ of $\mathrm{KBr}$ (IR-grade). A $7 \mathrm{~mm}$ pellet was made using a hand press (Qwik Handi-Press, Spectra-Tech Industries Corporation) without evacuation. The spectra were collected between 4,000 and $400 \mathrm{~cm}^{-1}$ at $4 \mathrm{~cm}^{-1}$ resolution. The presence of FTIR absorption of organic and inorganic phases was identified by using in-house or ad hoc spectral libraries (i.e., Weiner, 2010). Mineral magnetic parameters Mineral magnetic properties can reflect changes in iron mineralogy in soils, soft sediments, and hard rocks that result from diagenetic redox-processes, pedogenesis, and also thermal alteration. Thermal alteration leads to an enhancement of mineral magnetic parameters caused firstly by the thermal degradation of plant material and secondly by the transformation of para- and/or antiferromagnetic iron minerals to ferrimagnetics. This enhancement of mineral magnetic parameters can be identified by low field susceptibility and concentration of independent interparametric ratios derived from laboratory induced remanences (Dalan and Banerjee, 1998; Evans and Heller, 2003).

Sample preparation was conducted at the Laboratory for Palaeo- and Environmental Magnetism, Bayreuth University, Germany. The low field magnetic susceptibility was determined with a MAGNON Susceptibility Bridge (MAGNON, Dassel, Germany) at AC-fields of $300 \mathrm{~A} / \mathrm{m}$ at 0.3 and $3 \mathrm{kHz}$, respectively, and is given as mass specific susceptibility $(\chi)$. The frequency dependence of susceptibility $(\chi \mathrm{fd})(\chi \mathrm{fd} \%=[\chi(0.3 \mathrm{kHz})-\chi(3 \mathrm{kHz})] / \chi(0.3 \mathrm{kHz}) \times 100$ in $\%)$ is a measure of the 
relative contribution of SP-ferrimagnetica close to the SP-SD threshold. $\chi$ reflects concentration of ferrimagnetic minerals and also grain size distribution. Fine-grained superparamagnetic (SP) ferrimagnetica $(<0.03 \mu \mathrm{m})$ have a $2-3$ times higher $\chi$ than stable single-domain, pseudosingle-domain (SSD, PSD; $\sim 0.03-10 \mu \mathrm{m}$ ) and multidomain ferrimagnetica (MD, $>\sim 10 \mu \mathrm{m}$; Evans and Heller, 2003). Induced isothermal remanent magnetizations (IRMs) were determined after exposing the samples to a pulsed field of 2,000 and $200 \mathrm{mT}$ (back field), respectively, along one spatial axis. Magnetization was produced using a MAGNON PM II pulse magnetizer and measured via an AGICO JR6-spinner magnetometer (AGICO, Brno, Czech Republic). The IRM acquired in the $2 \mathrm{~T}$ field is regarded as saturation isothermal remanent magnetization (SIRM). As the SP-size fraction is defined by the absence of magnetic remanence under room temperature, IRMs are essentially controlled by the concentration of SSD to MD-ferrimagnetica. Furthermore, IRMs depend on the mineralogical composition with ferrimagnetica (magnetite, maghemite) being more easily magnetised than antiferromagnetica (goethite, hematite; Maher, 1986). Therefore, the modified S-ratio (=((IRM200mT ( IRM2000mT) + 1) / 2) is indicative of the relative abundance of ferrimagnetica to antiferromagnetica and a concentration-independent proxy (Walden et al., 1999; van Velzen and Deckers, 1999).

Anhysteretic remanent magnetizations (ARMs) were induced with a $50 \mu \mathrm{T}$ static field and $100 \mathrm{mT}$ alternating field (AF) amplitude using a Magnon AFD 300 demagnetizer. The ARM was produced along one spatial axis, and remanent magnetization was measured via the AGICO JR6spinner magnetometer. Similar to the IRM, the ARM reflects the concentration of remanence carrying magnetic phases. However, the ARM decreases more strongly from the SSD to the MD-fraction than does the SIRM. Therefore, the IRM/ARM ratio is a useful concentration-independent proxy for detecting changes in the ratio of SSD-MD fraction versus SSD fraction (Evans and Heller, 2003; Maher, 1986).

Thermoluminescence Thermoluminescence (TL) analysis can determine if sediment has been exposed to heating in the past by analysing the TL glow curve shapes and TL sensitivities. Luminescence has been frequently used to examine the presence of temperature-induced changes in sediment and subsequently to determine the age of heated sediment from archaeological contexts (Aitken, 1985; 
Alperson-Afil et al., 2007). Verification of prehistoric heating is usually done by the heating plateau test (Aitken, 1985), where a flat ratio of TL induced by artificial irradiation versus the natural TL signal provides evidence of the heating in the past. However, the material under study here is sediment, and bleaching of the signal during deposition or sampling could induce results comparable to heating. Therefore the heating plateau test alone is not proof of a prehistoric firing event. However, heating of minerals changes the sensitivity of the TL-signal and results in different shapes of the TLglow curves, which can indicate prehistoric heating.

Sample preparation was conducted at the Max Planck Institute for Evolutionary Anthropology in Leipzig, Germany. TL measurements were performed on a Risø Da-15 luminescence reader at $5 \mathrm{~K}$ $\mathrm{s}^{-1}$ to $450^{\circ} \mathrm{C}$ with immediate background subtraction. Luminescence detection with an EMI 9236QA photomultiplier was restricted to the UV-blue wavelength range by Corning 5-58 and KG-5 glass filters. Irradiations were performed with a calibrated external ${ }^{90} \mathrm{Sr} /{ }^{90} \mathrm{Y}$-source, and samples were stored at $50^{\circ} \mathrm{C}$ for one week before measurement. Prior to the luminescence study, the organic and carbonate content of this fine grained sediment was removed and the fine grain fraction $(4-11 \mu \mathrm{m})$ was extracted according to Stokes law.

Heating experiment Sample preparation and the heating experiment itself were performed at the Geoarchaeology Laboratory, University of Tübingen. Sediment samples from layer $4 b / c$ and layer $4 b$ from Schöningen 13 II-4 were subjected to a stepwise heating experiment. The samples were heated for 4 hours in a muffle furnace to temperatures of $100^{\circ} \mathrm{C}, 200^{\circ} \mathrm{C}, 300^{\circ} \mathrm{C}, 400^{\circ} \mathrm{C}, 500^{\circ} \mathrm{C}, 700^{\circ} \mathrm{C}$, $800^{\circ} \mathrm{C}, 900^{\circ} \mathrm{C}, 1000^{\circ} \mathrm{C}$, and $1100^{\circ} \mathrm{C}$, and subsequently cooled down for at least 24 hours in a desiccator. In a second run, no desiccator was employed to account for possible variance, but none was observed and only some test analyses of the mineral magnetic parameters were carried out on these. Color change and weight loss were recorded and further analyses were chosen based on these observations. The samples of layer $4 \mathrm{~b}$ were only studied macroscopically. For the samples of layer $4 \mathrm{~b} / \mathrm{c}$, study of the mineral magnetic parameters was conducted on the whole temperature range. Micromorphological analyses and FTIR spectroscopy were also performed on the samples from layer $4 \mathrm{~b} / \mathrm{c}$ between temperatures of $400^{\circ} \mathrm{C}$ to $1100^{\circ} \mathrm{C}$. Thermoluminescence analyses were conducted on 
samples from layer $4 \mathrm{~b} / \mathrm{c}$ heated to $400^{\circ} \mathrm{C}, 700^{\circ} \mathrm{C}$, and $900^{\circ} \mathrm{C}$. A non-heated sample from layer $4 \mathrm{~b} / \mathrm{c}$ was analyzed with micromorphology, FTIR, by study of the mineral magnetic parameters, and by thermoluminescence analyses.

\section{Results}

Hearths at Schöningen 13 II-4

Stahlschmidt et al. (2015) present a detailed analysis of the geological context of the purported hearth features and the following includes a short review of the geological context.

Geological context - layer 4b Layer 4b is composed of dark brown (Munsell Soil Color Chart 7.5YR 3/2) organic silt, which locally exhibits laminations. Layer $4 \mathrm{~b}$ has a variable but maximal thickness of $35 \mathrm{~cm}$. Under the microscope, layer $4 \mathrm{~b}$ is composed mostly of small $(<0.3 \mathrm{~mm})$, slightly humified fragments of plant tissue, with a minor portion of rounded, sand- to silt-sized grains of quartz and mica (Tables 3 and 4). Framboidal pyrite, diatoms, sponge spicules, and secondary nodules of gypsum were additionally noted in thin section. The microstructure is massive with some lamina distinguished by increased silt-sand-sized quartz and clay content. No evidence for heat alteration was found in this layer (Table 3).

Geological context- layer 4b/c Macroscopically, layer 4b/c is a calcareous mud with some mollusks that represent the only macroscopically identifiable materials in addition to the archaeological remains. Layer $4 \mathrm{~b} / \mathrm{c}$ exhibits minor soft sediment deformation, and it varies in color from brownish grey to grey (Munsell Soil Color Chart 2.5YR 6/3, 5/4, 6/1, and 10YR 5/8 to 4/6), which results from variable content of plant material, pyrite, and iron precipitations (see Stahlschmidt et al., 2015).

Microscopically, layer $4 \mathrm{~b} / \mathrm{c}$ consists of small $(<0.3 \mathrm{~mm})$, slightly humified fragments of plant tissue, pyrite, silt- to sand-sized quartz grains, diatoms, and shell fragments in a calcareous matrix (Fig. 7d, e; Table 3). 
Below the strongly reddened features interpreted as hearths, layer $4 \mathrm{~b} / \mathrm{c}$ appears slightly more red than the marls outside the purported hearth areas (Munsell Soil Color Chart 2.5YR 5/3). Excavators initially thought that this was also a result of heat alteration. However, the micromorphological analyses revealed the reddish colorations to result from localized iron oxidation associated with microscopic plant tissues and oxidation of the ubiquitous pyrite (see above). The general reflectance value of the plant tissue from layer $4 \mathrm{~b} / \mathrm{c}(0.17 \% \mathrm{Rr}$ to $0.22 \% \mathrm{Rr})$ indicates humification and gelification, not charring (Figure 8). Only very few, dispersed fragmented pieces of charred plant tissue were observed (Fig. 9). The recorded fluorescence color and intensity of the plant tissue are typical for the peat stage of plant tissue and corroborate the reflectance values.

Micromorphological analyses on layer $4 \mathrm{~b} / \mathrm{c}$ from outside the hearths showed no difference in components or structures from within the four hearths. Similarly, thermoluminescence analysis showed no difference in the glow curve shape and sensitivity in the sample from layer $4 \mathrm{~b} / \mathrm{c}$ from hearth 1 (Schö 13 II-4 FSI 2010/21 BT-1079; Fig. 10a and b) to that from outside the purported hearths (Schö 13II-4 2011/25 BT-1077; Fig. 10c and d). The heating plateau test indicates an apparent zeroing of the sample from hearth 1 (Fig. 10b), but the plateau is even more pronounced in the sample outside the hearths (Fig. 10d). Furthermore, heating as a single cause is revoked by bleaching experiments that showed the bleachability of the TL signal. Consequently, the presence of a plateau is not suited here for testing the occurrence of heating. A heating plateau is expected for luminescence not in saturation, but changes in sensitivities and especially glow curve shapes have to occur when sediment is heated. The sediment from layer $4 \mathrm{~b} / \mathrm{c}$ from outside the hearths was experimentally heated in the laboratory and shows an entirely different sensitivity and rather different glow curve shapes (Sch 13 II-4 Br Ex 4b/c LS 39 BT-1080, Fig. 10e) compared to the samples obtained from the Schöningen site (Fig. 10a and c). Taken together, these results suggest that the samples from hearth 1 and outside the hearths did not experience different temperatures.

$\underline{\text { Results of the heating experiment }}$ Table 5 provides an overview of the results of the heating experiment. The heated samples from layer $4 \mathrm{~b} / \mathrm{c}$ show a range of reactions starting from $100^{\circ}$ to $300^{\circ}$, 
at which point destruction of ferromagnetic Fe-sulfides occurs and neo-formation of para- and supermagnetic phases (SP) takes place (Fig. 11). Stable single domain (SSD) magnetite/maghemite forms at $400^{\circ} \mathrm{C}$ (Fig. 11). A macroscopic color change from greyish brown to pale brown was first observed at $500^{\circ} \mathrm{C}$ (Fig. 7f). The color change continues to reddish yellow (Munsell Soil Color 7.5YR 7/4-6/4) from 700 to $800^{\circ} \mathrm{C}$ and to light grey (Munsell Soil Color $10 \mathrm{YR} 7 / 2$ ) at $900^{\circ} \mathrm{C}$. The change in color noticed in our experiments is likely a result of 1) grey shell fragments and orange staining by iron oxidation at $\left.500^{\circ} \mathrm{C}, 2\right)$ blackened shell fragments and an increase in dark red and orange staining from $800^{\circ} \mathrm{C}$ onwards, 3) calcite depletion from 700 to $800^{\circ} \mathrm{C}$, and 4) destruction of magnetite/maghemite from $700-900^{\circ} \mathrm{C}$ with hematite formation at $800^{\circ} \mathrm{C}$ and $900^{\circ} \mathrm{C}$ (Figs. $7 \mathrm{~g}$ and 11 ). Furthermore, we observed that kaolinite is absent from samples heated to $400^{\circ} \mathrm{C}$, and that portlandite first appears at $700^{\circ} \mathrm{C}$ (Fig. 12) as a result of $\mathrm{CaO}$ re-hydration (Weiner, 2010). Finally, at $1000^{\circ} \mathrm{C}$ all Fe-bearing phases are transformed to magnetite/maghemite (Fig. 11). The shape of the TL signal changes as a result of laboratory heating as observed in the samples heated to $400^{\circ} \mathrm{C}, 700^{\circ} \mathrm{C}$, and $900^{\circ} \mathrm{C}$ (Fig. 10e). Additionally, for an identical dose the sensitivity is raised by a factor of seven compared to the regeneration of the sample from the purported hearths.

The reddening/purported hearth features The reddened contact between layers $4 \mathrm{~b} / \mathrm{c}$ and $4 \mathrm{~b}$ occupied horizontal spaces of 1 to $3 \mathrm{~m}^{3}$, varying among the four hearths. The reddened contact consists of a consolidated hard crust with a thickness of $2-3 \mathrm{~cm}$ and a brownish yellow to reddish yellow color (Munsell Soil Color 10YR 6/8- 7.5YR 6/6). Microscopically, the reddening is composed of amorphous iron that impregnated the groundmass of layers $4 \mathrm{~b}$ and $4 \mathrm{~b} / \mathrm{c}$. This reddening is in fact composed of several microlayers, which indicates multiple episodes of formation (Fig. 7a-c). Oxygen-rich water in combination with a redox (reduction/oxidation) boundary at the contact of the two layers brought about the massive precipitation of iron at the contact. Other spatially extensive iron oxidation features at similar sedimentary contacts were observed in the excavation area at Schöningen 13 II (Fig. 13). Moreover, the observation by the excavators that the reddened contact has grown vertically and horizontally over the years supports the assumption that the reddening represents a recent, on-going process, likely related to the recent groundwater lowering at the mine. 
Micromorphological analyses did not detect ash remains or phytoliths associated with the reddening and revealed only a few, isolated charcoal fragments. Reflectance values indicate generally low humification of the plant tissues. Organic petrology analysis observed very few, small $(<0.3 \mathrm{~mm})$ fragmented, charred particles and showed that the charred plant tissues are herbaceous (Table 4 and Fig. 14). Accordingly, they most likely derive from natural peat fires. Bone, ostracod, and mollusk shell fragments in thin section show no evidence for heat alteration (Fig. 7d, e; Table 3). Furthermore, FTIR analyses demonstrated the presence of kaolinite, which is not stable above temperatures of $400^{\circ} \mathrm{C}$ (Fig. 12). None of the experimentally produced heat alterations (charring of plant tissue, color change of shell fragments, formation of portlandite, hematite, magnetite, or calcite depletion) were observed on the material obtained from the purported hearths, and the local red staining observed in the heating experiment is unlike the reddening at the purported hearths (see above).

Burnt sediment from Schöningen 13 II-2 and 13 II-3

The reflectance values of the two sediment samples from Schöningen 13 II-2 and 13 II-3 show a mean value of $0.25 \% \mathrm{Rr}$ and a range from $0.10 \% \mathrm{Rr}$ to $0.45 \% \mathrm{Rr}$ (Fig. 15). These reflectance values are indicative of humification and not carbonization (which results in values greater than $\sim 0.6 \% \mathrm{Rr}$ ). Charred plant tissues (fusinites) are a rare occurrence in the sediment sample and are dominantly herbaceous and highly fragmented.

Burnt wood and sediment from Schöningen 12 B

The presumed burnt piece of wood is very well preserved and shows low reflectance values, $0.11 \% \operatorname{Rr}$ to $0.16 \% \operatorname{Rr}$ (Fig. 16), which are indicative of humification and not carbonization. No part of the wood piece showed reflectance values that indicate combustion (which would be $>0.6 \% \mathrm{Rr}$ ). Brown fluorescence of the cell walls shows that the wood sample is composed of humic substances in addition to lignin and cellulose. 


\section{Discussion}

No evidence for human use or control of fire at Schöningen

Our results show that the reddening at the purported hearths at Schöningen 13 II-4 did not result from heating but instead represents a natural, recent post-depositional process of iron precipitation and oxidation. Such reddened contacts of two overlying sedimentary layers are widely known features in lacustrine sequences (e.g., Deike et al., 1997; Kaczorek and Sommer, 2003). A few transported, charred plant tissues probably resulting from natural fires are the only evidence for fire at Schöningen 13 II (see also Urban et al., 2015). Palynological analyses (Stahlschmidt et al., 2015; Urban et al., 2015) document an increase in microcharcoal at several erosional contacts in the profile section 12 II and 13 II, which may indicate a change in frequency of natural fires resulting from shifts in climate or changing seasonality.

Furthermore, the organic petrology analyses show that the presumably burnt sediment from Schöningen 13 II-3 and purported burnt wood from Schöningen 12 B have not been exposed to heat. These results highlight the difficulty of using macroscopic identification of burnt sediment and charcoal without further verification, and call into question other burnt wood claimed as evidence for fire at Schöningen, such as the Bratspieß (e.g., Thieme, 2005; Schoch et al., 2015).

Lithic artifacts from Schöningen 13 I had been exposed to fire, as demonstrated by thermoluminescence analysis (Richter, 1998, 2007; Richter and Thieme, 2012; Richter and Krbetschek, in press). This being said, the association of burnt, possibly natural pieces of flint with archaeological remains does not demonstrate human use of fire (e.g., James et al., 1989; Roebroeks and Villa, 2011a). This particularly applies to burnt wood, which occurs naturally and is frequently preserved in lacustrine deposits (e.g., Power et al., 2010).

Implications for the archaeological record in northern latitudes 
Schöningen does not contain evidence for controlled or habitual use of fire. The results of our study on the reddened and black sediments at Schöningen call into question similar claims for human control of fire that are solely based on macroscopic, visual identification of reddened or dark-colored sediments. At Beeches Pit, Gowlett and colleagues (2005) identify hearths based on the presence of oxidized sediments overlain by dark-colored deposits. They note the spatial association of these features with clusters of burnt flint and bone. However, the inferred temperature of 350 to $800^{\circ} \mathrm{C}$ for the bones and lithic material does not exclude natural fires, and no analysis of the purported hearth sediments has yet been presented. A detailed micromorphological analysis of the purported hearths, as also proposed by Gowlett et al. (2005), would potentially be able to differentiate between natural and anthropogenic fire.

The lack of evidence for human induced fire at Schöningen, and the questionable evidence at Beeches Pit, leaves archaeologists with no conclusive evidence for human control of fire in northern latitudes during the Lower Paleolithic (Roebroeks and Villa, 2011a). This stands in contrast to the evidence for human occupation as early as 800,000 years ago above the $50^{\text {th }}$ degree of latitude in Europe (Parfitt et al., 2010). The lack of evidence for human use and control of fire could be either a result of poor preservation, human behavior, or both.

Preservation Surovell and Brantingham (2007) argue that the archaeological record is subject to taphonomic biases, which cause overrepresentation of younger periods relative to older periods (but see Surovell et al., 2009). The lack of early evidence for human use and control of fire in northern latitudes might also be a result of taphonomic processes erasing the evidence (Sandgathe et al, 2011b). Hearths and burnt materials can be subject to destructive processes, such as bioturbation, erosion, and chemical alterations (e.g., Sergant et al., 2006; Mallol et al., 2007; Braadbaart et al., 2009; Mentzer, 2012). Combustion features can also be influenced by geochemical conditions and modifications of the depositional environment (e.g., Shahack-Gross et al., 2004; Shahack-Gross et al., 2014). For example, in northern latitudes acidic soils predominate (e.g., Jones et al., 2010), which negatively affects ash preservation. However, charcoal shows better preservation under acidic, rather than 
alkaline conditions (Braadbaart et al., 2009). Caves and rockshelters exhibit very good preservation properties, as shown by the rich record of well-preserved hearth features in Middle Paleolithic sites in Europe, the Near East, and Africa (e.g., Goldberg and Bar-Yosef, 1998; Goldberg et al., 2009; Wadley et al., 2011). However, Lower Paleolithic sites in caves and rock shelters in Europe have not been reported to contain any evidence for human use of fire (e.g., Atapuerca Gran Dolina and Sima del Elefante, Arago, Treugol'naya , and Visogliano [Roebroeks and Villa 2011a]).

Most Lower Paleolithic sites in northern latitudes are located in open-air settings (e.g., Pakefield, Boxgrove, Happisburgh, Schöningen, Bilzingsleben), and sites in open-air settings are subject to more pronounced post-depositional alterations, such as bioturbation, erosion, and subaerial weathering (Goldberg and Sherwood, 2006). Sergant et al. (2006), in their investigation of a lack of Mesolithic hearths in the NW European plain, argue that unstructured hearths rarely preserve in this type of setting, since they are erased by bioturbation and erosion. Mallol et al. (2007) in an ethnographic study on the use of fire by the Hadza observed that taphonomic processes, such as root invasion and erosion, can erase hearths in open-air settings, but that microscopic traces are often preserved depending on sedimentation rate. Supporting those observations, Friesem et al. (2013) report on a Middle Paleolithic hearth in an open-air setting, noting that it was likely preserved because of rapid burial.

Human behavior Gowlett and Wrangham (2013) argue that a lack of natural fire in northern latitudes presented a limiting factor for human settlement there. However, whereas most of the Lower Paleolithic sites in Europe date to interglacials (e.g., Boxgrove, Bilzingsleben, Pakefield, Schöningen), there are sites occupied during unfavorable climatic conditions, such as Happisburgh (Parfitt et al., 2010). Sandgathe and colleagues (2011a, b) claim that Neanderthals did not practice habitual fire use and that they depended on natural sources of fire. However, contradicting Sandgathe et al.'s claim, Rots (2011, in press) presents evidence for ignition activities on a Levallois point at the site of Bettencourt, France. The current state of evidence strongly suggests that the first inhabitants of northern Europe did not habitually use and control fire (Roebroeks and Villa, 2011a). 
An independence from fire seems odd in the face of data indicating that modern humans cannot survive, even if fully acclimatized, to temperatures below $-5^{\circ} \mathrm{C}$ without some kind of protection against the cold in the form of clothing, fire, or shelter (Hardy et al., 1971; Gilligan, 2010). However, it is possible that archaic humans might have had a different temperature tolerance. In this context, providing warmth seems the most important application of fire next to providing nutritional improvement and light. Use of shelters, seasonal migration, a stronger reliance on animal food resource, clothing, and physical and nutritional adaptation present further strategies to cope with a colder environment (Gilligan, 2010).

Some Lower Paleolithic sites in Europe are situated in rock shelters and caves that could have provided protection. However, most of the known Lower Paleolithic record consists of open-air sites. The analysis of sites in open-air settings have not yet yielded reliable evidence for the construction of shelters in the Lower and Middle Paleolithic (cf. the controversial cases of Terra Amata [de Lumley, 1969], Chichibu [Hadfield, 2000], and Bilzingsleben [Mania and Mania, 2000]). Constructed shelters become a common feature of archaeological sites only in the Upper Paleolithic (Iakovleva and Djindjian, 2005; Svoboda et al., 2005).

Seasonal migration in winter to areas with less harsh climate or only ephemeral occupation have been suggested for Early Pleistocene occupation in northern latitudes (e.g., Roebroeks, 2001; Dennell, 2003, 2013), but high resolution data on seasonal signals and cold or warm phase occupation is often lacking. So far this option has been explored in detail only from the later Middle Paleolithic onward (e.g., Féblot-Augustins, 1993). Similarly, the fossil record of the Middle Pleistocene in northern latitudes is too sparse to ascertain a physical adaptation to colder climates, whereas with the Middle Paleolithic a cold-adapted species — the Neanderthals — appears in Europe (Sergi, 1944; Churchill, 1998; Steegmann et al., 2002; Snodgrass and Leonard, 2009; but see Rae et al., 2011). Some researchers suggest that an increase in the consumption of animal resources is a necessary adaptation in order to maintain a high metabolic rate when confronted with the rarity of plant food in northern latitudes (Snodgrass and Leonard, 2009; but see Speth, 2010). However, more detailed studies of edible plants in northern latitudes are still in progress (Bigga et al., 2015). The lack 
of vitamin C caused by the scarcity of plant food could have been answered with an increase of rawnot cooked — meat, especially liver, as is practiced by the Inuit (Höygaard, 1940; Draper, 1977). The spears from Schöningen are an excellent example of an improved hunting technology, and the richness of butchery remains at the site shows good access to animal resources (see also Dennell, 2013). Horsehide might also have been exploited as protection against the cold (Voormolen, 2008), and it is generally assumed that Neanderthals (e.g., Wales, 2012) depended on clothing to survive winter. The origin of clothing is still an open question since its preservation in Paleolithic context is very improbable. However, studies of needles, depictions, textile impressions, and the evolution of lice have provided some indirect evidence for Paleolithic clothing (e.g., Adovasio et al., 1996; Soffer et al., 1998; Soffer, 2004).

\section{Conclusion}

Since James et al.'s (1989) early critique on the various claims for human use and control of fire in the Paleolithic literature, the evaluation of evidence for fire has been approached in a much more circumspect manner and the associated human behavior is carefully classified into fire use, control, sporadic use and control, habitual use and control, and fire production. However, many claims for early use of fire still rest on unsubstantiated assumptions and "intuitive" claims. Our multianalytical, contextualized study at Schöningen is an example of a refutation of such types of unsupported claims. Our analysis on purported hearths, burnt sediment, wood, and lithic material, along with a critical reassessment of other claims for fire at Schöningen, clearly show that the site complex does not serve as an example of human use or control of fire in the Lower Paleolithic.

In order to investigate the human mastery of fire, archaeologists must conduct a three-step evaluation of their data. First, the researcher must demonstrate that the material evidence was either produced or altered by fire. As shown in this study, macroscopic, qualitative evidence for heat alteration is often ambiguous but can be verified with such techniques as micromorphology, Fourier transform infrared (FTIR) spectroscopy, organic petrology, luminescence, and analysis of mineral 
magnetic parameters. Second, the researcher must demonstrate that the heat alteration is related to human activity and is not the result of a natural process (e.g., forest fire or lightning strike); a micromorphological approach presents the most promising tool. Third, the researcher must evaluate whether the evidence suggests use of fire, control of fire, production of fire, or habitual use of fire.

The lack of direct evidence for human use and control of fire in northern latitudes does not serve as evidence for absence of such behavior, and it is still debatable if this lack of evidence is related to poor preservation or to human behavior. Accepting the null hypothesis would mean that unless material is proven to be burnt, it is not burnt, and that unless human fire use can be proven, humans did not use fire. Accordingly, the present data set in Europe suggests the absence of fire use and control in the Lower Paleolithic. More in-depth research along the lines used in this study is needed to find and evaluate evidence for early fire use in northern latitudes.

\section{Acknowledgements}

This work was largely funded by DFG grant CO 226/22-1. We are grateful to the Niedersächsische Landesamt für Denkmalpflege (NLD) and the Niedersächsisches Ministerium für Wissenschaft und Kultur (MWK) for cooperation and support. We would like to thank the National Science Foundation (\#0073856; 0551927) for support. MS would like to thank the Athene program for support. We are also indebted to S. Winghardt, P.Kritikakis, S. Mentzer, J. Bega, the Schöningen excavation team, and J. Lehmann. D.R. would like to thank Manfred Fischer (Bayreuth) for sample preparation and TL measurement. We are thankful to the anonymous reviewers for their helpful comments to an earlier version of this manuscript.

The authors declare no competing financial interests.

C.E.M., P.G., J.S., and N.J.C. conceived the project; M.C.S., C.E.M., and J.S. performed sampling and field analysis; M.C.S., C.E.M., P.G., and F.B. performed micromorphological analysis; B.L. 
performed organic petrology; U.H. performed mineral magnetic parameters studies; D.R. performed thermoluminescence studies; F.B. performed mFTIR analysis; M.C.S. and C.E.M. designed the heating experiment, and M.C.S. wrote the paper. 


\section{References}

Adovasio, J., Soffer, O., Bohuslay, K., 1996. Upper Paleolithic fibre technology: interlaced woven finds from Pavlov I, Czech Republic, c. 26,000 years ago. Antiquity 70, 526-534.

Ahlers, S.A., 1983. Heat treatment of Knife River flint. Lithic Technology 12, 1-8.

Aitken, M.J., 1985. Thermoluminescence Dating. Academic Press, London.

Aldeias, V., Goldberg, P., Sandgathe, D., Berna, F., Dibble, H.L., McPherron, S.P., Turq, A., Rezek, Z., 2012. Evidence for Neandertal use of fire at Roc de Marsal (France). J. Archaeol. Sci. 39, 7, 2414-2423.

Alperson-Afil, N., 2008. Continual fire-making by hominins at Gesher Benot Ya'aqov, Israel. Quatern. Sci. Rev. 27, 1733-1739.

Alperson-Afil, N., Goren-Inbar, N., 2006. Out of Africa and into Eurasia with controlled use of fire: evidence from Gesher Benot Ya'aqov, Israel. Archaeol. Ethnol. Anthropol. Eurasia 28, 63-78.

Alperson-Afil, N., Goren-Inbar, N., 2010. The Acheulian Site of Gesher Benot Ya'aqov Volume II. Springer, Netherlands.

Alperson, N., Richter, D., Goren-Inbar, N., 2007. Phantom hearths and controlled use of fire at Gesher Benot Ya'aqov, Israel. PaleoAnthropology 2007, 1-15.

Ashton N., Lewis S.G., Parfitt, S.A., Penkman, K.E.H. ,Coope, G.R. 2008. New evidence for complex climate change in MIS 11 from Hoxne, Suffolk, UK. Quatern. Sci. Rev. 27, 652-668.

Avery, G., Kandel, A., Klein, R.G., Conard, N.J., Cruz-Uribe, K., 2004. Tortoises as food and taphonomic elements in palaeo « landscapes ». In: Brugal, J.-P., Jesse, D. (Eds.), Petits animaux et sociétés humaines. Du complément alimentaire aux ressources utilitaires XXIV, pp. 147-161.

Backhouse, P.N., Johnson, E., 2007. Where were the hearths: an experimental investigation of the archaeological signature of prehistoric fire technology in the alluvial gravels of the Southern Plains. J. Archaeol. Sci. 34, 1367-1378. 
Barbetti, M., 1986. Traces of fire in the archaeological record, before one million years ago? J. Hum. Evol. 15, 771-781.

Batchelder, R.B., 1967. Spatial and temporal patterns of fire in the tropical world. Proc. A. Tall Timbers Fire Ecol. Conf. 6, 171-207.

Bellomo, R.V., 1993. A methodological approach for identifying archaeological evidence of fire resulting from human activities. J. Archaeol. Sci. 20, 525-553.

Bellomo, R.V., 1994. Methods of determining early hominid behavioral activities associated with the controlled use of fire at FxJj 20 Main, Koobi Fora, Kenya. J. Hum. Evol. 27, 173-195.

Berna, F., Goldberg, P., 2008. Assessing Paleolithic pyrotechnology and associated hominin behavior. Isr. J. Earth Sci. 56, 107-121.

Berna, F., Goldberg, P., Horwitz, L.K., Brink, J., Holt, S., Bamford, M., Chazan, M., 2012. Microstratigraphic evidence of in situ fire in the Acheulean strata of Wonderwerk Cave, Northern Cape province, South Africa. Proc. Natl. Acad. Sci. 109, E1215-E1220.

Bigga, G., Schoch, W.H., Urban, B., in press. Paleoenvironment and possibilities of plant exploitation in the Middle Pleistocene of Schöningen (Germany). Insights from botanical macro-remains and pollen. J. Hum. Evol.

Binford, L.R., Ho, C.K., Aigner, J.S., Alimen, M.-H., Borrero, L.A., Te-K-un, C., Chung, T., Goldberg, P., Ikawa-Smith, F., Lanata, J.L., Zune, L., Luchterhand, K., Lyman, R.L., Mengoni Goñalons, G., Pei, G., Straus, L.G., Yacobaccio, H.D., Yi, S., 1985. Taphonomy at a distance: Zhoukoudian, "The Cave Home of Beijing Man"? Curr. Anthropol. 26, 413-442.

Bittmann, F., 2012. Die Schöninger Pollendiagramme und ihre Stellung im mitteleuropäischen Mittelpleistozän. In: Behre, K.-E. (Ed.), Die chronologische Einordnung der paläolithischen Fundstellen von Schöningen. Forschungen zur Urgeschichte aus dem Tagebau von Schöningen Band 1. Verlag des Römisch-Germanischen Zentralmuseums, Mainz, pp. 97-112. Bordes, F., 1957. Review of K.P. Oakley 'Fire as a paleolithic tool and weapon'. L'Anthropologie 61, $314-317$ 
Braadbaart, F., Poole, I., van Brussel, A.A., 2009. Preservation potential of charcoal in alkaline environments: an experimental approach and implications for the archaeological record. J. Archaeol. Sci. 36, 1672-1679.

Brace, L., Rosenberg, K.R., Hunt, K.D., 1987. Gradual change in human tooth size in the Late Pleistocene and Post-Pleistocene. Evolution 41, 705-720.

Brain, C.K., 1991. The Hunters or the Hunted? An Introduction to African Cave Taphonomy. University of Chicago Press, Chigago.

Brain, C.K., Sillen, A., 1988. Evidence from the Swartkrans cave for the earliest use of fire. Nature $336,464-466$.

Brandes, C., Pollok, L., Schmidt, C., Wilde, V., Winsemann, J., 2012. Basin modelling of a lignitebearing salt rim syncline: insights into rim syncline evolution and salt diapirism in NW Germany. Basin Res. 24, 699-716.

Brewer, S., 1978. The chimps of Mt. Asserik. Knopf, New York.

Brown, K.S., Marean, C.W., Herries, A., Jacobs, Z., Tribolo, C., Braun, D., Roberts, D.L., Meyer, M.C., Bernatchez, J., 2009. Fire as an engineering tool of early modern humans. Science 325, $859-862$.

Buenger, B.A., 2003. The impact of wildland and prescribed fire on archaeological resources. Ph.D. dissertation, University of Kansas.

Christian, H.J., Blakeslee, R.J., Boccippio, D.J., Boeck, W.L., Buechler, D.E., Driscoll, K.T., Goodman, S.J., Hall, J.M., Koshak, W.J., Mach, D.M., Stewart, M.F., 2003. Global frequency and distribution of lightning as observed from space by the Optical Transient Detector. J. Geophys. Res. 108(D1), 4005, doi:10.1029/2002JD002347.

Churchill, S.E., 1998. Cold adaptation, heterochrony, and Neandertals. Evol. Anthropol. 7, 46-60.

Clark, J.D., Harris, J.W.K., 1985. Fire and its roles in early hominid lifeways. Afr. Archaeol. Rev. 3, $3-27$.

Clark, J.D., Kurashina, H., 1979. Hominid occupation of the East-Central Highlands of Ethiopia in the Plio-Pleistocene. Nature 282, 33-39. 
Clark, J.L., Ligouis, B., 2010. Burned bone in the Howieson's Poort and post-Howieson's Poort Middle Stone Age deposits at Sibudu (South Africa): behavioral and taphonomic implications. J. Archaeol. Sci. 37, 2650-2661.

Clark, J.D., Asfaw, B., Assefa, G., Harris, J.W.K., Kurashina, H., Walter, R.C., White, T.D., Williams, M.A.J., 1984. Paleoanthropological discoveries in the Middle Awash Valley, Ethiopia. Nature $307,423-428$.

Coolidge, F.L., Wynn, T., 2009. The rise of Homo sapiens: the evolution of modern thinking. WileyBlackwell, Chichester, UK.

Courty, M.A., Goldberg, P., Macphail, R., 1989. Soils and Micromorphology in Archaeology. Cambridge University Press, Cambridge.

Dalan, R.A., Banerjee, S.K., 1998. Solving archaeological problems using techniques of soil magnetism. Geoarchaeology 13, 3-36.

Daniau, A.-L., d'Errico, F., Sánchez Goñi, M.F., 2010. Testing the hypothesis of fire use for ecosystem management by Neanderthal and Upper Palaeolithic modern human populations. PLoS ONE 5, e9157. doi:10.1371/journal.pone.0009157

Davis, K.P., 1959. Forest Fire-Control and Use. McGraw-Hill, New York.

DeBano, L.F., Neary, D.G., Ffolliott, P.F., 1998. Fire's Effects on Ecosystems. John Wiley and Sons, Chichester, UK.

Deike, R.G., Granina, L., Callender, E., McGee J.J., 1997. Formation of ferric crusts in Quaternary sediments of Lake Baikal, Russia, and implications for paleoclimate. Mar. Geol. 139, $21-46$.

Dennell, R., 2003. Dispersal and colonisation, long and short chronologies: how continuous is the early Pleistocene record for hominids outside East Africa? J. Hum. Evol. 45, 421-440.

Dennell, R., 2013. The Nihewan Basin of North China in the Early Pleistocene: continuous and flourishing, or discontinuous, infrequent and ephemeral occupation? Quatern. Int. 295, 223236. 
Draper, H.H., 1977. The aboriginal Eskimo diet in modern perspective. Am. Anthropol. 79, 309-316.

Ehlers, J., Eissmann, L., Lippstreu, L., Stephan, H.-J., Wansa, S., 2004. Pleistocene glaciations of North Germany. In: Ehlers, J., Gibbard, P.L. (Eds.), Quaternary Glaciations. Extent and Chronology Part I, Europe. Dev. Quatern. Sci. 2, 135-146.

Elsner, H., 2003. Das Quartär im Tagebau Schöningen der Braunschweigischen Kohlenbergwerke AG, Helmstedt. Diploma thesis, University of Hannover.

Evans, M.E., Heller, F., 2003. Environmental magnetism - principles and applications of Enviromagnetics. Academic Press, San Diego.

Féblot-Augustines, J., 1993. Mobility strategies in the late Middle Paleolithic of Central Europe and Western Europe: elements of stability and variability. J. Anthropol. Archaeol. 12, 211-265.

Fessler, D.M.T., 2006. A burning desire: steps toward an evolutionary psychology of fire learning. J. Cognition Culture 6, 429-451.

Frazer, J.G., 1930. Myths of the origin of fire: an essay. Macmillan, London.

Friesem, D.E., Zaidner, Y., Shahack-Gross, R., 2013. Formation processes and combustion features at the lower layers of the Middle Palaeolithic open-air site of Nesher Ramla, Israel. Quatern. Int. $331,128-138$.

Gaudzinski, S., Roebroeks, W., 2000. Adults only. Reindeer hunting at the Middle Palaeolithic site Salzgitter Lebenstedt, Northern Germany. J. Hum. Evol. 38, 497-521.

Geyh, M.A., Krbetschek, M., 2012. Zum radiometrischen Alter des Holstein-Interglazials. In: Behre, K.-E. (Ed.), Die chronologische Einordnung der paläolithischen Fundplätze von Schöningen. Forschungen zur Urgeschichte aus dem Tagebau von Schöningen Band 1. Verlag des Römisch-Germanischen Zentralmuseums, Mainz, pp. 151-170.

Geyh, M.A., Müller H., 2005. Numerical 230Th/U dating and a palynological review of the Holsteinian/Hoxnian Interglacial. Quatern. Sci. Rev. 24, 1861-1872.

Gilligan, I., 2010. The prehistoric development of clothing: archaeological implications of a thermal model. J. Archaeol. Method Th. 17, 17-80. 
Goldberg, P., 2003. Some Observations on Middle and Upper Palaeolithic Ashy Cave and Rockshelter Deposits in the Near East. In: Goring-Morris, A.N., Belfer-Cohen, A. (Eds.), More than meets the Eye: Studies on Upper Palaeolithic Diversity in the Near East. Oxbow Books, UK, pp. 1932.

Goldberg, P., 2004. Micromorphology of Pech-de-l’ Azé II Sediments. J. Archaeol. Sci. 6, 17-47.

Goldberg, P., Bar-Yosef, O., 1998. Site formation processes in Kebara and Hayonim Caves and their significance in Levantine Prehistoric Caves. In: Akazawa, T., Aoki, K., Bar-Yosef, O. (Eds.), Neandertals and Modern Humans in Western Asia. Plenum Press, New York, pp. 107-125.

Goldberg, P., Sherwood, S., 2006. Deciphering human prehistory through the geoarchaeological study of cave sediments. Evol. Anthropol. 15, 20-36.

Goldberg, P., Weiner, S., Bar-Yosef, O., Xu, Q., Liu, J., 2001. Site formation processes at Zhoukoudian, China. J. Hum. Evol. 41, 483-530.

Goldberg, P., Miller, C.E., Schiegl, S., Ligouis, B., Berna, F., Conard, N.J., Wadly, L., 2009. Bedding, hearths, and site maintenance in the Middle Stone Age of Sibudu Cave, KwaZulu-Natal, South Africa. Archaeol. Anthropol. Sci. 1, 95-122.

Goldberg, P., Dibble, H., Berna, F., Sandgathe, D., McPherron, S.J.P., Turq, A., 2012. New evidence on Neandertal use of fire: examples from Roc de Marsal and Pech de l'Azé IV. Quatern. Int. 247, 325-340.

Goren-Inbar, N., Alperson, N., Kislev, M.E., Simchoni, O., Melamed, Y., Ben-Nun, A., Werker, E., 2004. Evidence of hominin control of fire at Gesher Benot Ya'aqov, Israel. Science 304, 725 727.

Goudsblom, J., 1986. The human monopoly on the use of fire: its origins and conditions. Hum. Evol. $1,517-523$.

Gowlett, J.A.J., 2006. The early settlement of northern Europe: fire history in the context of climate change and the social brain. C. R. Palevol. 5, 299-310.

Gowlett, J.A.J., Wrangham, R., 2013. Earliest fire in Africa: towards the convergence of archaeological evidence and the cooking hypothesis. Anzania: Archaeol. Res. Afr. 48, 1, 5-30. 
Gowlett, J.A.J., Harris, J.W.K., Walton, D., Wood, B.A., 1981. Early archaeological sites, hominid remains and traces of fire from Chesowanja, Kenya. Nature 294, 125-129.

Gowlett, J.A.J., Harris, J.W.K., Walton, D., Wood, B.A., 1982. Reply to Isaac. Nature 296, 870.

Gowlett, J.A.J., Hallos, J., Hounsell, S., Brant, V., Debenham, N.C., 2005. Beeches Pit - archaeology, assemblage dynamics and early fire history of a Middle Pleistocene site in East Anglia, UK. Eurasian Prehist. 3, 3-38.

Hadfield, P., 2000. Gimme shelter. New Sci. 165, 2228, 4.

Hanson, M., Cain, C.R., 2007. Examining histology to identify burned bone. J. Archaeol. Sci. 34, 1902-1913.

Hardy, J.D., Stolwijk, J.A.J., Gagge, A.P., 1971. Man. In: Whittow, G.C. (Ed.), Comparative Physiology of Thermoregulation. Volume II: Mammals. Academic, New York, pp. 327-380.

Hendey, Q.B., 1976. The Pliocene fossil occurrences in 'E' quarry, Langebaanweg, South Africa. Ann. S. Afr. Mus. 69, 215-247.

Hough, W., 1926. Fire as an agent in human culture. Government Printing Office, Washington.

Höygaard, A., 1940. Im Treibeisgürtel. Als Arzt unter Grönländischen Eskimos. Georg Westermann Verlag, Braunschweig.

Iakovleva, L., Djindjian, F., 2005. New data on Mammoth bone settlements of Eastern Europe in light of the new excavations of the Gontsy site (Ukraine). Quatern. Int. 126-128, 195-207.

Isaac, G.L., 1977. Olorgesailie: Archaeological Studies of a Middle Pleistocene Lake Basin in Kenya. University of Chigago Press, Chigago.

Isaac, G.L., 1982. Early hominids and fire at Chesowanja, Kenya. Nature 296, 870.

Isaac, G.L., 1984. The archaeology of human origins: studies of the Lower Pleistocene in East Africa 1971-1981. Adv. World Archaeol. 3, 1-87.

Isaac, G.L., Harris, J.W.K., 1997. Sites stratified within the KBS tuff. In: Isaac, G.L. (Ed.), Koobi Fora Research Project Volume 5: Plio-Pleistocene Archaeology. Clarendon Press, Oxford, pp. 71-99. 
James, S.R., Dennell, R.W., Gilbert, A.S., Lewis, H.T., Gowlett, J.A., Lynch, T.F., McGrew, W.C., Peters, C.R., Pope, G.G., Stahl, A.B., 1989. Hominid use of fire in the Lower and Middle Pleistocene: a review of the evidence. Curr. Anthropol. 30, 1-26.

Jones, T.P., Lim, B., 2000. Extraterrestrial impacts and fire. Palaeogeogr. Palaeoclimatol. Palaeoecol. 164, 57-66.

Jones, A., Montanarella, L., Stolbovoy, V., Broll, G., Tarnocai, C., Spaargaren, O., Ping, C.-L., 2010. Soil atlas of the Northern Circumpolar Region. European Commission, Luxembourg.

Kaczorek, D., Sommer, M., 2003. Micromorphology, chemistry, and mineralogy of bog iron ores from Poland. Catena 54, 393-402.

Karkanas, P., Shahack-Gross, R., Ayalon, A., Bar-Matthews, M., Barkai, R., Frumkin, A., Gopher, A., Stiner, M.C., 2007. Evidence for habitual use of fire at the end of the Lower Paleolithic: site formation processes at Qesem Cave, Israel. J. Hum. Evol. 53, 197-212.

Klein, R.G., 2002. The Dawn of Human Culture. John Wiley and Sons, New York.

Klein, R.G., 2009. The Human Career: Human Biological and Cultural Origins. The University of Chicago Press, Chicago.

van Kolfschoten, T., 2014. The Palaeolithic locality Schöningen (Germany): a review of the mammalian record. Quatern. Int. 326-327, 469-480.

Lang, J., Winsemann, J., Steinmetz, D., Polom, U., Pollok, L., Böhner, U., Serangeli, J., Brandes, C., Hampel, A., Winghart, S., 2012. The Pleistocene of Schöningen, Germany: a complex tunnel valley fill revealed from 3D subsurface modelling and shear wave seismics. Quatern. Sci. Rev. $39,86-105$.

Ligouis, B., 2006. Jais, lignite, charbon et autres matières organiques fossiles: application de la pétrologie organique à l'étude des éléments de parure et des fragments bruts. In: Bullinger, J., Leesch, D., Plumettaz, N. (Ed.), Le site magdalénian de Monruz, 1. Premiers éléments pour l'analyse d'un habitat de plein air. Service et Musée Cantonal d'Archéologie, Neuchâtel, pp. $197-216$. 
Litt, T., Behre, K.-E., Meyer, K.-D., Stephan, H.-J., Wansa, S., 2007. Stratigraphische Begriffe für das Quartär des norddeutschen Vereisungsgebietes. Eisz. Gegenw. 56, 7-65.

de Lumley, H., 1969. A Paleolithic camp at Nice. Sci. Am. 220, 42-50.

de Lumley, H., 2006. Il y a 400000 ans: la domestication du feu, un formidable moteur d'homisation. C. R. Palevol 5, 149-154.

Maher, B.A., 1986. Characterisation of soils by mineral magnetic measurements. Phys. Earth Planet. Int. 42, 76-92.

Mallol, C., Marlowe, F.W., Wood, B.M., Porter, C.C., 2007. Earth, wind, and fire: ethnoarchaeological signals of Hadza fires. J. Archaeol. Sci. 34, 2035-2052.

Mania, D., 1991. Zur Paläontologie der mittelpleistozänen Travertine von Bilzingsleben. In: Bilzingsleben IV. Veröff. Landesmus. Vorgesch. Halle 44, Berlin, pp. 9-28.

Mania, D., 1995. Die geologischen Verhältnisse im Gebiet von Schöningen. In: Thieme, H., Maier, R. (Eds.), Archäologische Ausgrabungen im Braunkohlentagebau Schöningen. Landkreis Helmstedt, Hannover, pp. 33-43.

Mania, D., 2007. Das Eiszeitalter und seine Spuren im Tagebau Schöningen. In: Thieme, H. (Ed.), Die Schöninger Speere - Mensch und Jagd vor 400.000 Jahren. Theiss Verlag, Stuttgart, pp. $35-61$.

Mania, D., Mania U., 2000. Der Urmensch von Bilzingsleben - Ein Lebensbild vor 400.000 Jahren. In: Hansch, W. (Ed.), Eiszeit - Mammut, Urmensch... und wie weiter? Städtische Museen Heilbronn, Heilbronn, pp. 116-137.

Mentzer, S., 2012. Microarchaeological approaches to the identification and interpretation of combustion features in prehistoric archaeological sites. J. Archaeol. Method Th. 1-53.

Mercier, N., Froget, L., Miallier, D., Pilleyre, T., Sanzelle, S., Tribolo, C., 2004. Nouvelles données chronologiques pour le site de Menez-Dregan 1 (Bretagne): l'apport de la thermoluminescence. Quaternaire 15, 253-261.

Monnier, J.-L., Hallégouët, B., Hinguant, S., Laurent, M., Auguste, P., Bahain, J.-J., Falguères, C., Gebhardt, A., Marguerie, D., Molines, N., Morzadec, H., Yokoyama, Y., 1994. A new 
regional group of the Lower Paleolithic in Brittany (France), recently dated by Electron Spin Resonance. C. R. Acad.Sci. 319, 155-60.

Monnier, J.-L., Hallegouet, B, Hinguant, S., Molines, N., 2001. La Datation de l'habitat paléolithique inférieur de Menez-Dregan 1 (Plouhinec, Finistère, France): argumentation géologique et archéologique. In: Barradon, J.-N., Guibert, P., Michel, V. (Eds), DATATION XXI rencontres internationales d'archéologique et d'historie d'Antibes. APDCA, pp. 261-277.

Oakley, K.P., 1955. Fire as a Paleolithic tool and weapon. Proc. Prehist. Soc. 21, 36-48.

Parfitt, S.A., Ashton, N.M., Lewis, S.G., Abel, R.L., Coope, R., Field, M.H., Gale, R., Hoare, P.G., Larkin, N.R., Lewis, M.D., Karloukovski, V., Maher, B.A., Peglar, S.M., Preece, R.C., Whittaker, J.E., Stringer, C.B., 2010. Early Pleistocene human occupation at the edge of the boreal zone in northwest Europe. Nature 466, 229-233.

Power, M.J., Marlon, J.R., Bartlein, P.J., Harrison, S.P., 2010. Fire history and the Global Charcoal Database: a new tool for hypothesis testing and data exploration. Palaeogeogr. Palaeoclimatol. Palaeoecol. 291, 52-59.

Preece, R.C., Gowlett, J.A.J., Parfitt, S., Bridgland, D.R., Lewis, S.G., 2006. Humans in the Hoxnian: habitat, context and fire use at Beeches Pit, West Stow, Suffolk, UK. J. Quatern. Sci. 21, $485-496$.

Preece, R.C., Parfitt, S.A., Bridgland, D.R., Lewis, S.G., Rowe, P.J., Atkinson, T.C., Candy, I., Debeham, N.C., Penkman, K.E.H., Rhodes, E.J., Schwenninger, J.-L., Griffiths, H.I., Whittaker, J.E., Gleed-Owen, C., 2007. Terrestrial environments during MIS 11: evidence from the Paleolithic site at West Stow, Suffolk, UK. Quatern. Sci. Rev. 26, 1236-1300.

Pruetz, J.D., LaDuke, T.C., 2010. Brief communication: Reaction to fire by savanna chimpanzees (Pan troglodytes verus) at Fongoli, Senegal: conceptualization of "fire behavior" and the case for a chimpanzee model. Am. J. Phys. Anthropol. 141, 646-650.

Purdy, B.A., 1971. Investigations Concerning the Thermal Alteration of Silica Minerals: An Archaeological Approach. Ph.D. dissertation, University of Florida. 
Purdy, B.A., 1975. Fractures for the Archaeologist. Lithic technology In: Swanson, E.H. (Ed.), Lithic Technology. Mouton, Chicago, pp. 133-141.

Purdy, B.A., Brooks, H.K., 1971. Thermal alteration of silica minerals: an archeological approach. Science $173,322-325$.

Pyne, S.J., Andrews, P.L., Laven, R.D., 1996. Introduction toWildland Fire. Wiley, New York.

Rae, T.C., Koppe, T., Stringer, C.B., 2011. The Neanderthal face is not cold adapted. J. Hum. Evol. $60,234-239$.

Rice, S.A., 2007. Encyclopedia of evolution. Facts On File, New York.

Richter, D., 1998. Thermolumineszenzdatierungen erhitzter Silices aus paläolithischen Fundstellen. Ph.D. dissertation, University of Tübingen.

Richter, D., 2007. Altersbestimmung der Fundschichten von Schöningen mit dosimetrischen Datierungsmethoden. In: Thieme, H. (Ed.), Die Schöninger Speere - Mensch und Jagd vor 400,000. Konrad Theiss, Stuttgart, pp. 62-66.

Richter, D., Krbetschek, M., in press. Luminescence dating of the Lower Palaeolithic occupation at Schöningen. J. Hum. Evol.

Richter, D., Thieme, H., 2012. One first chronometric date for the Lower Palaeolithic occupation at Schöningen 13 I. In: Behre, K.-E. (Ed.), Die chronologische Einordnung der paläolithischen Fundplätze von Schöningen. Forschungen zur Urgeschichte aus dem Tagebau von Schöningen Band 1. Verlag des Römisch-Germanischen Zentralmuseums, Mainz, pp. 171182.

Roebroeks, W., 2001. Hominid behaviour and the earliest occupation of Europe: an exploration. J. Hum. Evol. 41, 437-461.

Roebroeks, W., Villa, P., 2011a. On the earliest evidence for habitual use of fire in Europe. Proc. Natl. Acad. Sci. 108, 5209-5214.

Roebroeks, W., Villa, P., 2011b. Reply to Sandgathe et al.: Neandertal use of fire. Proc. Natl. Acad. Sci. 108, 299. 
Rolland, N., 2004. Was the emergence of home bases and domestic fire a punctuated event? A review of the Middle Pleistocene record in Eurasia. Asian Perspect. 34, 248-280.

Rots, V., 2011. Tool Use and Hafting in the Western European Middle Palaeolithic. Bulletin de la Société royale belge d'études géologiques et archéologiques - Les Chercheurs de laWallonie. Hors-série 4, 277-287.

Rots, V., in press. Hafting and the interpretation of site function in the European Middle Palaeolithic. In: Conard, N.J. (Ed.), Settlement Dynamics of the Middle Palaeolithic and Middle Stone Age, Vol. 4. Kerns Verlag, Tübingen.

Sandgathe, D.M., Dibble, H.L., Goldberg, P., McPherron, S.P., Turq, A., Niven, L., Hodgkins, J., 2011a. On the role of fire in Neandertal adaptations in western Europe: evidence from Pech de l’Azé IV and Roc de Marsal, France. PaleoAnthropology 216-242.

Sandgathe, D.M., Dibble, H.L., Goldberg, P., McPherron, S.P., Turq, A., Niven, L., Hodgkins, J., 2011b. Timing of the appearance of habitual fire use. Proc. Natl. Acad. Sci. 108, 298.

Schiegl, S., Thieme, H., 2007. Auf den Spuren von Feuer in Schöningen 13 II-4. In: Thieme, H. (Ed.), Die Schöninger Speere - Mensch und Jagd vor 400,000 Jahren. Theiss Verlag, Stuttgart, pp. 166-171.

Schiegl, S., Stockhammer, P., Scott, C., Wadley, L., 2004. A mineralogical and phytolith study of the Middle Stone Age in Sibudu Cave, KwaZulu-Natal, South Africa. S. Afr. J. Sci. 100, 185194.

Schoch, W.H., Bigga, G., Böhner, U., Richter, P., Terberger, T., 2015. New insights on the wooden weapons from the Paleolithic site of Schöningen. J. Hum. Evol.

Scott, A.C., 1989. Observations on the nature and origin of fusain. Int. J. Coal Geol. 12, 443-475.

Scott, A.C., 2000. The Pre-Quaternary history of fire. Palaeogeogr. Palaeoclimatol. Palaeoecol. 164, $281-329$

Serangeli, J., Böhner, U., 2012. Die Artefakte von Schöningen und deren zeitliche Einordnung. In: Behre, K.-E. (Ed.), Die chronologische Einordnung der paläolithischen Fundplätze von 
Schöningen. Forschungen zur Urgeschichte aus dem Tagebau von Schöningen Band 1. Verlag des Römisch-Germanischen Zentralmuseums, Mainz, pp. 23-38.

Serangeli, J. Conard, N.J., 2015. New results from large-scale excavations in Schöningen. J. Hum. Evol.

Serangeli, J., Böhner, U., Haßmann, H., Conard, N.J., 2012. Die pleistozänen Fundstellen in Schöningen - eine Einführung. In: Behre, K. (Ed.), Die chronologische Einordnung der paläolithischen Fundstellen von Schöningen. Forschungen zur Urgeschichte aus dem Tagebau von Schöningen Band 1. Verlag des Römisch-Germanischen Zentralmuseums, Mainz, pp. 122.

Sergant, J., Crombé, P., Perdaen, Y., 2006. The "invisible" hearths: a contribution to the discernment of Mesolithic non-structured surface hearths. J. Archaeol. Sci. 33, 999-1007.

Sergi, S., 1944. Craniometria e craniografia del primo paleantropo di Saccopastore. Ric. Morfol. 20$21,733-791$.

Shahack-Gross, R., Bar-Yosef, O., Weiner, S., 1997. Black-coloured bones in Hayonim Cave, Israel: differentiating between burning and oxide staining. J. Archaeol. Sci. 24, 439-446.

Shahack-Gross, R., Berna, F., Karkanas, P., Weiner, S., 2004. Bat guano and preservation of archaeological remains in cave sites. J. Archaeol. Sci. 31, 1259-1272.

Shahack-Gross, R., Berna, F., Karkanas, P., Lemorini, C., Gopher, A., Barkai, R., 2014. Evidence for the repeated use of a central hearth at Middle Pleistocene (300 ky ago) Qesem Cave, Israel. J. Archaeol. Sci. 44, 12-21.

Shipman, P., Foster, G.F., Schoeninger, M., 1984. Burnt bones and teeth: an experimental study of colour, morphology, crystal structure and shrinkage. J. Archaeol. Sci. 11, 307-325.

Snodgrass, J., Leonard, W.R., 2009. Neandertal energetics revisited: insights into population dynamics and life history evolution. PaleoAnthropology 2009, 220-237.

Soffer, O., 2004. Recovering perishable technologies through use wear on tolls: preliminary evidence for Upper Paleolithic weaving and net making. Curr. Anthropol. 45, 407-413. 
Soffer, O., Advasio, J.M., Hyland, D.C., Klima, B., Svoboda, J., 1998. Perishable technologies and the genesis of the eastern Gravettian. Anthropologie 36, 43-68.

Sorenson, A., Roebroeks, W., van Gijn, A., 2014. Fire production in the deep past? The expedient strike-a-light model. J. Archaeol. Sci. 42, 476-486.

Speth, J., 2010. The Paleoanthropology and Archaeology of Big-Game Hunting - Protein, Fat, or Politics? Springer, New York.

Stach, E., Mackowsky, M.-T., Teichmüller, M., Taylor, G.H., Chandra, D., Teichmüller, R., 1975. Stach’s Textbook of Coal Petrology. Gebrüder Bornträger, Berlin.

Stahl, A.B., Dunbar, R.I.M., Homewood, K., Ikawa-Smith, F., Kortlandt, A., McGrew, W.C., Milton, K., Paterson, J.D., Poirier, F.E., Sugardjito, J., Tanner, N.M., Wrangham, R.W., 1984. Hominid dietary selection before fire. Curr. Anthropol. 25, 151-168.

Stahlschmidt, M.C., Miller, C.E., Ligouis, B., Goldberg, P., Berna, F., Urban, B., Conard, N.J., in press. The depositional environments of Schöningen 13 II-4 and their archaeological implications. J. Hum. Evol.

Steegmann, A., Cerny, F., Holliday, T., 2002. Neandertal cold adaptation: physiological and energetic factors. Am. J. Hum. Biol. 14, 566-583.

Steguweit, L., 2003. Gebrauchsspuren an Artefakten der Hominidenfundstelle Bilzingsleben (Thüringen). Verlag Marie Leidorf, Rahden.

Stiner, M.C., Kuhn, L., Weiner, S., Bar-Yosef, O., 1995. Differential burning, recrystallization, and fragmentation of archaeological bone. J. Archaeol. Sci. 22, 223-237.

Stoops, G., 2003. Guidelines for Analysis and Description of Soil and Regolith Thin Sections. Soil Science Society of America, Madison, WI.

Stoops, G., Marcelino, V., Mees, F. (Eds.), 2010. Interpretation of Micromorphological Features of Soils and Regoliths. Elsevier, Amsterdam.

Straus, L., 1989. On early hominid use of fire. Curr. Anthropol. 30, 488-491.

Surovell, T.A., Brantingham, P.J., 2007. A note on the use of temporal frequency distributions in studies of prehistoric demography. J. Archaeol. Sci. 34, 1868-1877. 
Surovell, T.A., Finley, J.B., Smith, G.M., Brantingham, P.J., Kelly, R., 2009. Correcting temporal frequency distributions for taphonomic bias. J. Archaeol. Sci. 36, 1715-1742.

Svoboda, J., Péan, S., Wojtal, P., 2005. Mammoth bone deposits and subsistence practices during MidUpper Palaeolithic in Central Europe: three cases from Moravia and Poland. Quatern. Int. $126-128,209-221$.

Taylor, G.H., Teichmüller, M., Davis, A., Diessel, C. F. K., Littke, R., Robert, P., 1998. Organic Petrology. Gerbrüder Borntraeger, Berlin.

Terberger, T., Schoch, W.H., Bigga, G., Böhner, U., Richter, P., in press. New insights on the wooden weapons from the Paleolithic site of Schöningen. J. Hum. Evol.

Thieme, H., 1997. Palaeolithic hunting spears from Germany. Nature 385, 807-810.

Thieme, H., 1999. Altpaläolithische Holzgeräte aus Schöningen, Lkr. Helmstedt. Bedeutsame Funde zur Kulturentwicklung des frühen Menschen. Germania 77, 451-487.

Thieme, H., 2002. Schöningen - Fundchronik Niedersachsen 2001. Nachrichten aus Niedersachsens Urgeschichte 8, 11-13.

Thieme, H., 2005. The Lower Palaeolithic art of hunting: the case of Schöningen 13 II-4, Lower Saxony, Germany. In: Gamble, C., Porr, M. (Eds.), The hominid individual in context: archaeological investigations of Lower and Middle Palaeolithic landscapes, locales and artefacts. Routeledge, London, pp. 115-132.

Thieme, H., 2007a. Ein Befund von Weltbedeutung: Ein Wildpferd-Jagdlager vor 400000 Jahren Die Holzgeräte: Speere, Wurfstock, Bratspieß. In: Thieme, H. (Ed.), Die Schöninger Speere Mensch und Jagd vor 400000 Jahren. Theiss-Verlag, Stuttgart, pp. 144-157.

Thieme, H., 2007b. Überlegungen zum Gesamtbefund des Wildpferd-Jagdlagers. In: Thieme, H. (Ed.), Die Schöninger Speere - Mensch und Jagd vor 400000 Jahren. Theiss-Verlag, Stuttgart, pp. $177-190$.

Thieme, H., 2007c. Die paläolithische Fundstelle Schöningen 12 (Reinsdorf-Warmzeit) - Eine dreimonatige Rettungsgrabung 1992 in $15 \mathrm{~m}$ Tiefe. In: Thieme, H. (Ed.), Die Schöninger Speere - Mensch und Jagd vor 400000 Jahren. Theiss-Verlag, Stuttgart, pp. 192-201. 
Thieme, H., 2007d. Eine neu entdeckte Warmzeit in Schöningen: Das Reinsdorf-Interglazial - Zur Anwesenheit des Menschen während der Reinsdorf-Warmzeit. In: Thieme, H. (Ed.), Die Schöninger Speere - Mensch und Jagd vor 400000 Jahren. Theiss-Verlag, Stuttgart, pp. 124-126.

Thieme, H., 2007e. Der Zerlegungsplatz der Jagdbeute. In: Thieme, H. (Ed.), Die Schöninger Speere Mensch und Jagd vor 400000 Jahren. Theiss-Verlag, Stuttgart, pp. 172-173.

Thieme, H., Maier, R., 1995. Archäologische Ausgrabungen im Braunkohlentagebau Schöningen, Landkreis Helmstedt. Verlag Hahnsche Buchhandlung, Hannover.

Tutin, C.E.G., White, L.J.T., Mackanga-Missandzou, A., 1996. Lightening strike burns large forest tree in the Lopé Reserve, Gabon. Global Ecol. Biogeogr. 5, 26-42.

Urban, B., 1995. Palynological evidence of younger Middle Pleistocene Interglacials (Holsteinian, Reinsdorf, Schöningen) in the Schöningen open cast lignite mine (eastern Lower Saxony, Germany). Mededelingen Rijks Geol. Dienst 52, 175-186.

Urban, B., 2007. Interglacial pollen records from Schöningen, North Germany. In: Sirocko, F., Claussen, M., Goni, M.F.S., Litt, T., (Eds.), The Climate of Past Interglacials. Dev. Quatern. Sci. 7, 418-444.

Urban, B., Sierralta, M., 2012. New palynological evidence and correlation of Early Palaeolithic sites Schöningen 12 B and 13 II, Schöningen open lignite mine. In: Behre, K.-E. (Ed.), Die chronologische Einordnung der paläolithischen Fundplätze von Schöningen. Forschungen zur Urgeschichte aus dem Tagebau von Schöningen Band 1. Verlag des Römisch-Germanischen Zentralmuseums, Mainz, pp. 77-96.

Urban, B., Lenhard, R., Mania, D., Albrecht, B., 1991a. Mittelpleistozän im Tagebau Schöningen, Ldkrs. Helmstedt. Z. Dt. Geol. Gesellschaft 142, 351-372.

Urban, B., Elsner, H., Hölzer, A., Mania, D., Albrecht, B., 1991b. Eine eem-und frühweichselzeitliche Abfolge im Tagebau Schöningen, Landkreis Helmstedt. Eisz. Gegenw. 41, 85-99.

Urban, B., Bigga, G., Böhner, U., van Kolfschoten, T., 2015. Environmental reconstruction and biostratigraphy of Upper Middle Pleistocene lakeshore deposits at Schöningen. J. Hum. Evol. 
Vallverdú, J., Vaquero, M., Cáceres, I., Allué, E., Rosell, J., Saladié, P., Chacón, G., Ollé, A., Canals, A., Sala, R., Courty, M.A., Carbonell, E., 2010. Sleeping activity area within the site structure of archaic human groups. Evidence from Abric Romani Level N combustion activity areas. Curr. Anthropol. 51, 137-145.

van Velzen, A.J., Deckers, M.J., 1999. Low-temperature oxidation of magnetite in loess-paleosol sequences: a correction of rock magnetic parameters. Stud. Geophys. Geod. 43, 357-375.

Vértes, L., Dobosi, V.T., 1990. Fireplaces of the settlement. In: Kretzoi, M., Dobosi, V.T. (Eds.), Vértesszöllös. Akademiai Kiado, Budapest, pp. 519-521.

Villa, P., 1982. Conjoinable pieces and site formation processes. Am. Antiq. 47, 276-310.

Villa, P., 1983. Terra Amata and the Middle Pleistocene Archaeological Record of Southern France. University of California Press, Berkeley.

Voormolen, B., 2008. Ancient hunters, modern butchers: Schöningen 13 II-4, a kill-butchery site dating from the northwest European Lower Palaeolithic. Ph.D. dissertation, Leiden University.

Wadley, L., Sievers, C., Bamford, M., Goldberg, P., Berna, F., Miller, C., 2011. Middle Stone Age bedding construction and settlement patterns at Sibudu, South Africa. Science 334, 13881391.

Walden, J., Oldfield, F., Smith, J. P., 1999. Environmental Magnetism: A Practical Guide. Technical Guide Series, no. 6. Quaternary Research Association, London.

Wales, N., 2012. Modeling Neanderthal clothing using ethnographic analogues. J. Hum. Evol. 63, $781-795$

Weiner, J., 2003. Friction vs. percussion. Some comments on firemaking from Old Europe. Bull. Primit. Technol. 26, 19-16.

Weiner, J., Floss, H., 2005. Eine Schwefelkiesknolle aus dem Aurignacien vom Vogelherd, BadenWürttemberg - Zu den Anfängen der Feuererzeugung im europäischen Paläolithikum. Archäol. Inf. 27, 59-78.

Weiner, S., 2010. Microarchaeology-Beyond the Visible Archaeological Record. Cambridge University Press, New York. 
Weiner, S., Xu, Q., Goldberg, P., Liu, J., Bar-Yosef, O., 1998. Evidence for the use of fire at Zhoukoudian, China. Science 281, 251-253.

Wrangham, R.W., 2009. Catching Fire: How Cooking Made Us Human. Basic Books, New York.

Wrangham, R.W., Conklin-Brittain, N., 2003. Review: 'Cooking as a biological trait'. Comp. Biochem. Physiol. Part A 136, 35-46.

Wrangham, R.W., Jones, H.J., Laden, G., Pilbeam, D., Conklin-Brittain, N., 1999. The raw and the stolen: cooking and the ecology of human origins. Curr. Anthropol. 40, 567-594.

Wu, R. (Ed.), 1985. Multi-disciplinary Study of the Peking Man Site at Zhoukoudian. Science Press, Beijing. 


\section{Figure captions}

Fig. 1. Location of Schöningen in Northern Germany. Green, light blue, red, and dark blue lines indicate the maximum extent of the glacial ice sheets $(E=$ Elsterian; $D=$ Saalian Drenthe; $W A=$ Saalian Warthe; WE= Weichselian; modified from Lang et al., 2012:87).

Fig. 2. Simplified, schematic sequence at Schöningen 13 II (after Mania [in Thieme, 1999:463 and Urban, 2007], modified according to Lang et al. [2012]; see also Stahlschmidt et al., 2015). 1 and 2) Elsterian glaciolacustrine deposits; 3) Lacustrine deposits; 4-7) Reinsdorf Interglacial shallowing cycles of the lake Schöningen 13 II-1 to II-4, with calcareous mud grading into an overlaying dark organic mud: 4) cycle 1;5) cycle 2; 6) cycle 3; 7) cycle 4; note the location of Schöningen 13 II-4 in cycle 4 and 13 II-2 and II-3 in cycles 2 and 3;8) $5^{\text {th }}$ shallowing cycle, composed of sandy silt and an overlaying dark organic mud; 9 and 10) Glaciolacustrine deposits; 11) Lacustrine deposits and loess. See Figure 3 for the position of the profile.

Fig. 3. Map of Schöningen sites discussed here. The Schöningen sites are located in an open-cast mine and the sites Schöningen 13 II and 12 B are associated with sediments from the second major cycle of lacustrine deposition. The approximate 13 II profile position refers to Figure 2. Note, however, that the profile in Figure 2 continues further east (after Mania in Thieme, 1999:457 and Serangeli et al., 2012: 14).

Fig. 4. Schematic map of Schöningen 13 II-4 showing find density and the locations of the four purported hearths (modified after Thieme, 2007e:173; see also Stahlschmidt et al., 2015) and the reference samples Schö 13II-4 2003/3. The excavation area Schöningen 13 II-4 is cut by mining activities to the north, east, and south, and the actual size dimension of the find horizon is therefore not known. Colored in dark grey is the approximate area of highest find density, in medium grey of 
medium find density, and in light grey of low find density. The schematic sequence depicted in Figure 2 was taken at the northern edge of the excavation area Schöningen 13 II-4 (thick line).

Fig. 5. Photo of the crack running through Schöningen 13 II-3 and 13 II-2. The crack runs through the calcareous marl of 13 II-3 and across organic mud of 13 II-2. The crack was filled with black sediment, which was interpreted as a possible heat-altered sediment. Samples were taken at the contact of Schöningen 13 II-2 with 13 II-3 and the "X" illustrates the approximate location of the samples. Photo by W. Mertens CNLD.

Fig. 6. Sedimentary sequence at the purported hearth 1 at Schöningen 13 II-4. The sedimentary sequence at the purported hearths at Schöningen 13 II-4 consists of a calcareous marl, layer 4c, at the base, overlain by a transitional layer, layer $4 \mathrm{~b} / \mathrm{c}$, exhibiting an increase in organic matter, which in turn is overlain by an organic mud, layer $4 b$. The contact between layer $4 b / c$ and layer $4 b$ is overprinted by an indurated, reddened crust, which was interpreted as the result of heat alteration (Thieme, 1997, 2005). The squares show the approximate locations of samples for micromorphology, FTIR, and organic petrology (all "M"), for study of mineral magnetic parameters ("P"), and for thermoluminescence analysis ("TL"). Note the recent bioturbation (refilled channel) and drying features (cracks). Photo by J. Lehmann CNLD.

Fig. 7. Thin section analyses in layer $4 \mathrm{~b} / \mathrm{c}$, the reddening and the heating experiment. A: Scan of thin section Sch FS 1 03B showing the reddening and the lower layer 4b/c. Note the laminated appearance of the reddening. B: Microphotograph of reddening. Note again the laminated appearance of the reddening. Scale lower right $5 \mathrm{~mm}$, Plane-polarized light (PPL). C: The reddening at higher magnification showing the impregnation of layer $4 \mathrm{~b} / \mathrm{c}$ by amorphous iron. Scale at lower right $1 \mathrm{~mm}$, PPL. D: Microphotograph of shell fragments in layer $4 \mathrm{~b} / \mathrm{c}$ directly below the reddening. Note that the shell fragments show no evidence for heat alteration contrary to what was replicated by the heating experiment (see F and G). Scale at lower right $0.2 \mathrm{~mm}$, PPL. E: Microphotograph of layer 4b/c below 
the reddening. Note the abundance of pyrite (yellow arrows), brown plant tissues, and a bone fragment (yellow circle). None of these components show evidence for heat alteration. Scale at lower right 0.1 $\mathrm{mm}$, PPL. F: Microphotograph of the calcareous marl heated to $500^{\circ} \mathrm{C}$. Note the grey coloring of the shell fragments (yellow arrows) and localized red staining (yellow circle). Scale at lower right, 0.2 $\mathrm{mm}$, PPL. G: Microphotograph of the calcareous marl heated to $800^{\circ} \mathrm{C}$. Calcite depletion is visible here and hematite (pinkish color) formation. Note also the black color of the two shell fragments. Scale at lower right $0.5 \mathrm{~mm}$, PPL.

Fig. 8. Huminite reflectance histogram of layer 4c/b in sample Schö 13 II-4 FS11a. The reflectance values range from $0.17 \% \mathrm{Rr}$ to $0.28 \% \mathrm{Rr}$, which indicates low humification of the plant tissue and not carbonization.

Fig. 9. Microphotograph in reflected light of a polished block from layer $4 b$ at hearth 1 . Two fragments of charred herbaceous-derived tissue (white) occur next to numerous fragments of mixed, not burnt huminitic herbaceous-derived tissues. Scale at the left $50 \mu \mathrm{m}$.

Fig. 10. A and B. TL glow curves of sample Schö 13-II FS1 2010/21.2 (BT-1079) from layer 4b/c in hearth 1.

A: The blue curves (NTL) show the natural TL, the red lines $(\mathrm{NTL}+\mathrm{b})$ the TL signal produced by an additional artificial irradiation $(200 \mathrm{~Gy})$, and the green lines $\left(450^{\circ} \mathrm{C} / \mathrm{b}\right)$ the TL-signal after identical irradiation of the sample after measurement of the NTL.

B: Ratio of NTL $+b$ over NTL (heating plateau test) shows apparent zeroing. C and D. TL glow curves of sample Schö 13II-4 2011/25 BT-1077 from layer 4b/c outside the hearths.

C: The blue curves (NTL) show the natural TL, the red lines (NTL+b) the TL signal produced by an additional artificial irradiation $(200 \mathrm{~Gy})$, and the green lines $\left(450^{\circ} \mathrm{C} / \mathrm{b}\right)$ the TL-signal after identical irradiation of the sample after measurement of the NTL. Note the similar shape of the glow curves attained in the hearth 1 sample. Fig. 9a. 
D: the ratio of NTL+b over NTL (heating plateau test) shows apparent zeroing.

E: TL glow curves of sample Schö 13-II BrEx 4b/c LS 39 (BT- 1080) which is layer 4b/c heated to $400^{\circ} \mathrm{C}$. The blue curves $\left(400^{\circ} \mathrm{C}\right)$ show the residual $\mathrm{TL}$ after heating, the red lines $\left(400^{\circ} \mathrm{C}+\mathrm{b}\right)$ show the TL signal produced by an artificial irradiation (200 Gy), and the green lines the TL-signal after identical irradiation of the sample after measurement of the residual. Note the clear difference in sensivity and shape of glow curves compared to the samples from hearth 1 and outside the hearths in Fig. 9a and c.

Fig. 11. Changes of mineral magnetic parameters with heating up to $1100^{\circ} \mathrm{C}$. Concentrationdependent- parameters are plotted at the left (orange $=\mathrm{IRM} @ 2 \mathrm{~T}[\mathrm{~A} / \mathrm{m}]$ value, grey $=\mathrm{X}\left[\mathrm{m}^{3} \mathrm{~kg}^{-1}\right]$ value $)$ and mineral and grain size indicative inter-parametric ratios are shown at the right (green $=\mathrm{K}_{\mathrm{fd}}[\%]$ value, blue purple $=\mathrm{S}$-parameter, red purple $=\mathrm{IRM} / \mathrm{K}[\mathrm{A} / \mathrm{m}]$ ratio). The dashed lines mark the respective values of the reddened layer at the purported hearth. Note that there is no temperature interval where the magnetic characteristics of the reddened layer correspond to the experimental results. Several magneto-mineralogical changes were observed with increasing temperatures: $\leq 300^{\circ} \mathrm{C}$ destruction of ferrimagnetic Fe-sulfides and neo-formation of para- and superparamagnetic (SP) phases occurs; $\leq 700^{\circ} \mathrm{C}$ neo-formation of SP phases AND of stable single domain (SSD) magnetite/maghemite can be observed; $\leq 900^{\circ} \mathrm{C}$ : increasing neo-formation of hematite occurs; up to $1100^{\circ} \mathrm{C}$ transformation of all Fe-bearing phases to SSD magnetite/maghemite occurs.

Fig. 12. a) Representative FTIR spectrum of local marl sediment showing the IR absorptions of kaolinite $\left(3,620\right.$ and 3,695 $\left.\mathrm{cm}^{-1}\right)$ and calcite $\left(2,516\right.$ and 2,875-2,982 $\left.\mathrm{cm}^{-1}\right)$; b) Representative FTIR spectrum of local marl sediment heated to $500^{\circ} \mathrm{C}$ showing the abatement of kaolinite IR absorptions $\left(3,620\right.$ and 3,695 $\left.\mathrm{cm}^{-1}\right)$; c) Representative FTIR spectrum of local marl sediment heated to $700^{\circ} \mathrm{C}$ showing the IR absorption of portlandite $[\mathrm{Ca}(\mathrm{OH}) 2]\left(3,644 \mathrm{~cm}^{-1}\right)$ and the abatement of kaolinite IR absorptions $\left(3,620\right.$ and 3,695 $\left.\mathrm{cm}^{-1}\right)$. 
Fig. 13. Photograph of the contact of a lower calcareous marl with an upper organic mud/peat deposit at Schöningen 13 II-1. Note the iron precipitation at this contact, which is similar to the purported hearth features in 13 II-4. Height of profile about $1.20 \mathrm{~m}$.

Fig. 14. Huminite reflectance histogram of the reddening in sample Schö 13 II-4 FS 13a and 13b. The reflectance values range from $0.03 \% \mathrm{Rr}$ to $0.31 \% \mathrm{Rr}$, which indicates low humification of the plant tissue and not carbonization.

Fig. 15. Huminite reflectance histogram of the purported burnt sediment Schö 13 II-2/3 2010/35\&36. The reflectance values show a mean value of $0.25 \% \mathrm{Rr}$ and a range from $0.10 \% \mathrm{Rr}$ to $0.4 \% \mathrm{Rr}$, which is indicative of humification and not carbonization.

Fig. 16. Huminite reflectance histogram of the purported burnt wood ID 13325 . The reflectance values range from $0.11 \% \mathrm{Rr}$ to $0.16 \% \mathrm{Rr}$. This values indicate humification and not carbonization. 


\section{Figure's}

Figure 1

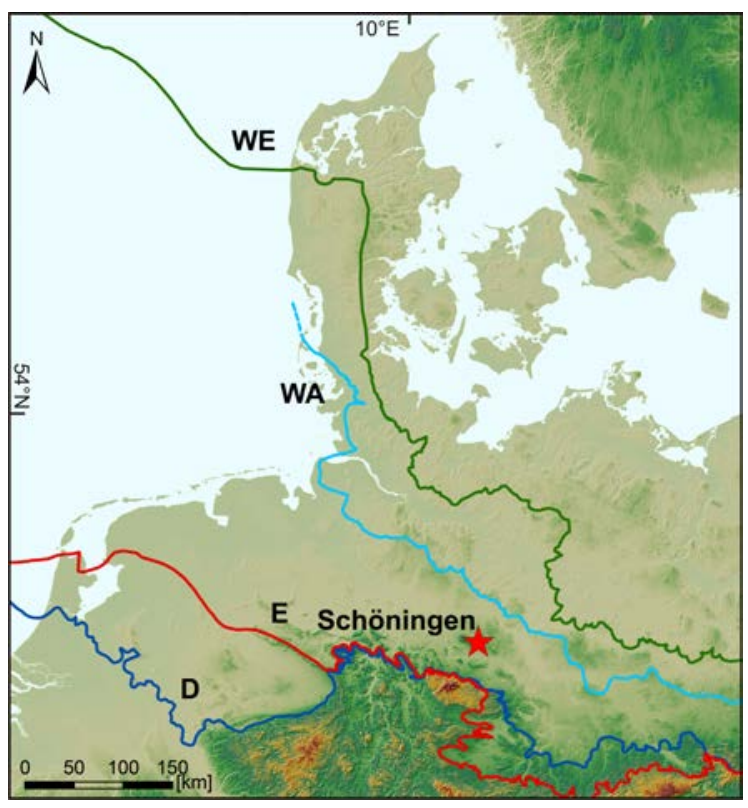




\section{Figure 2}

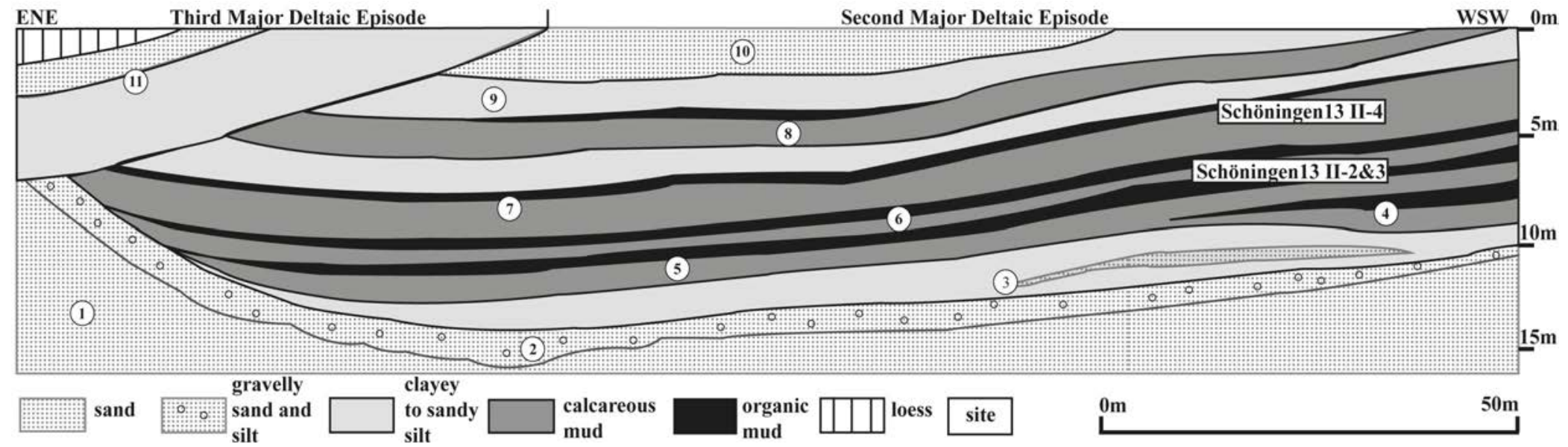


Figure 3

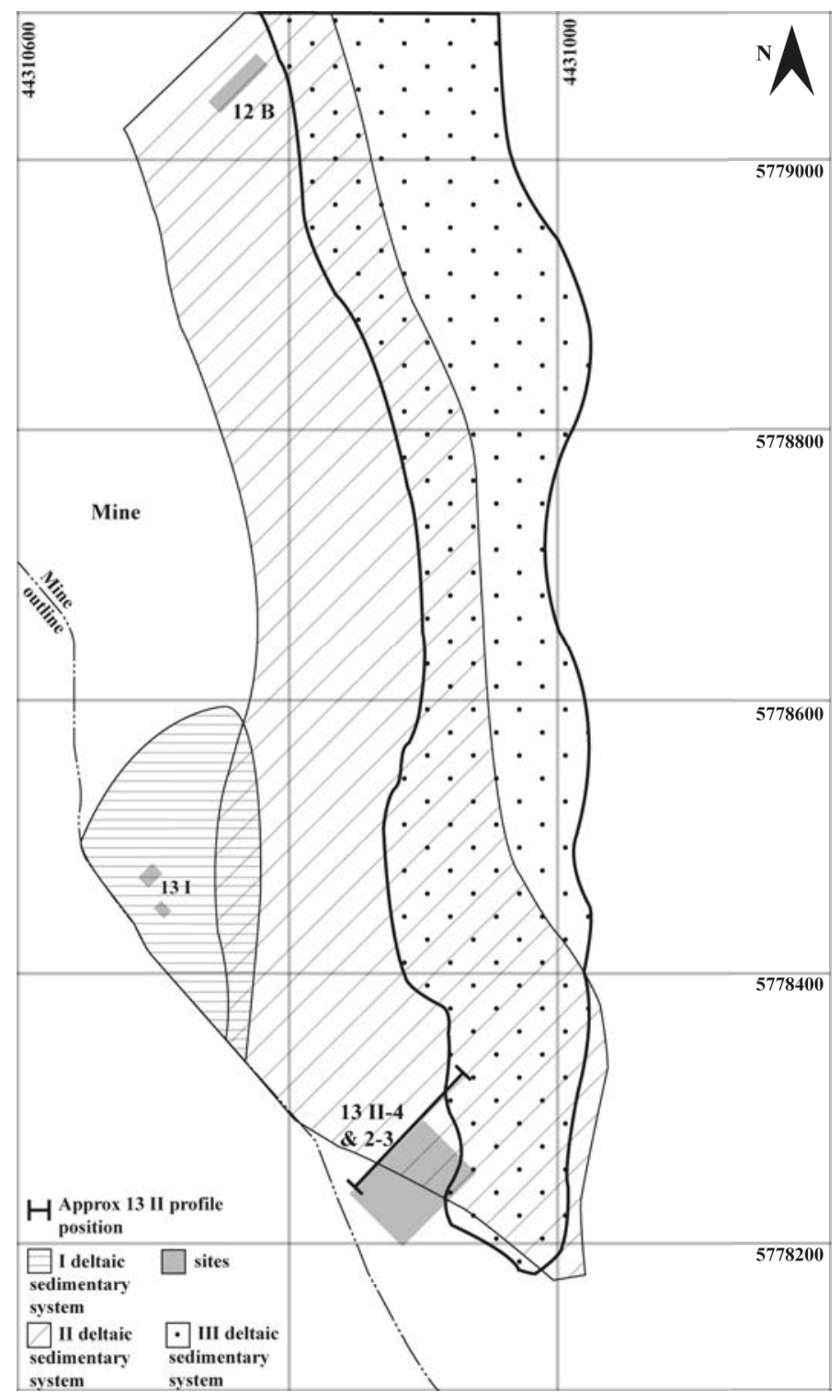


Figure 4

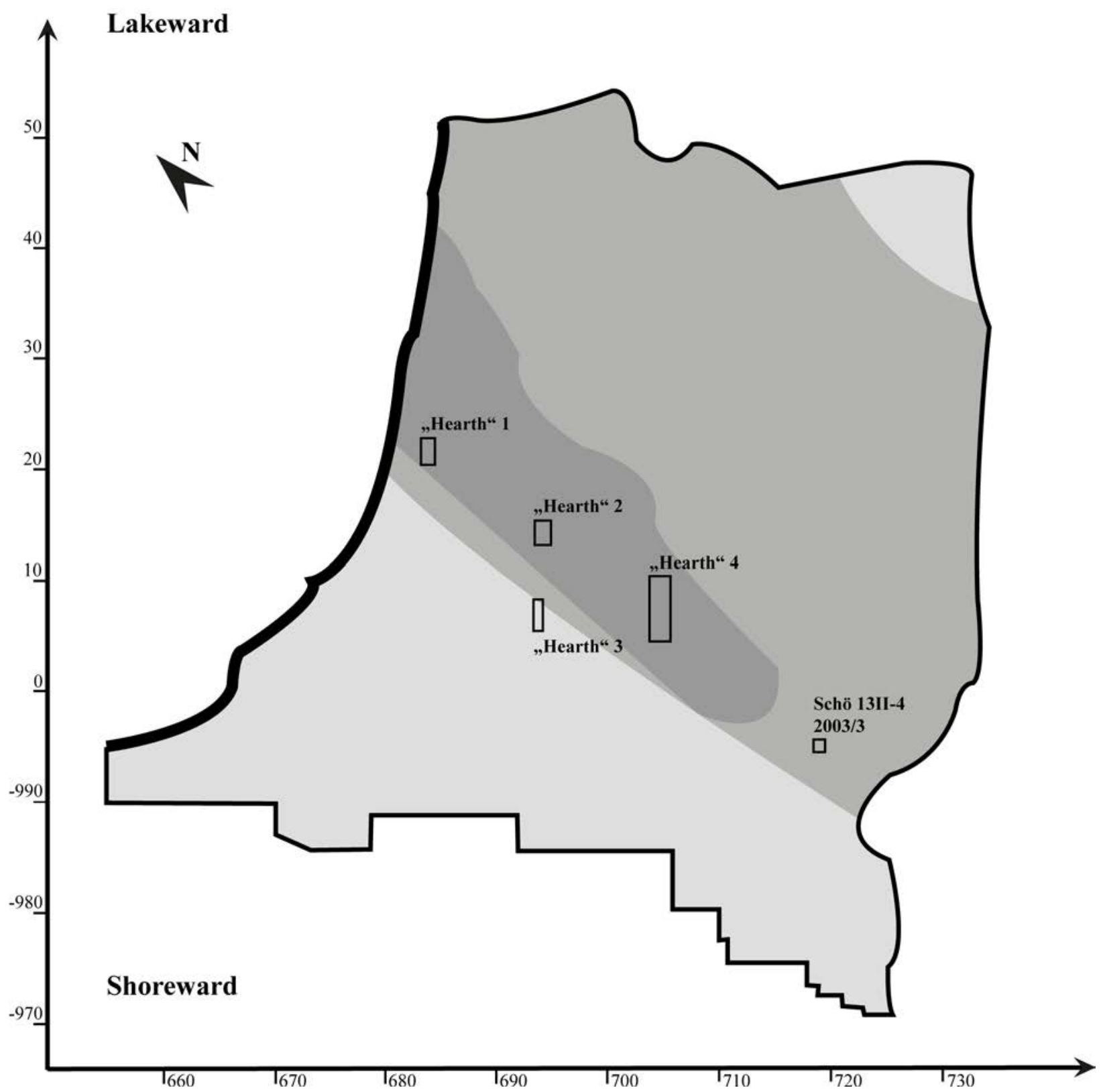


Figure 5

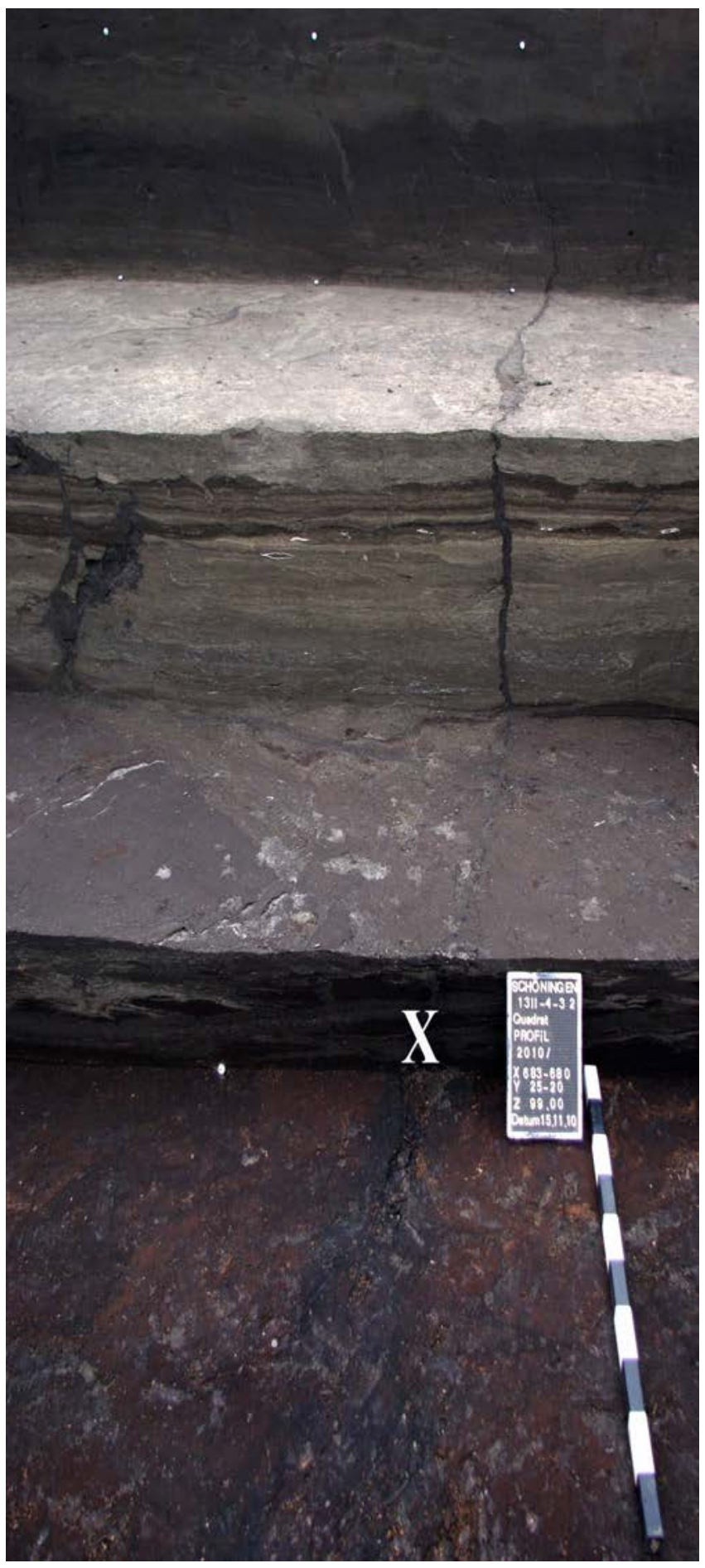


Figure 6

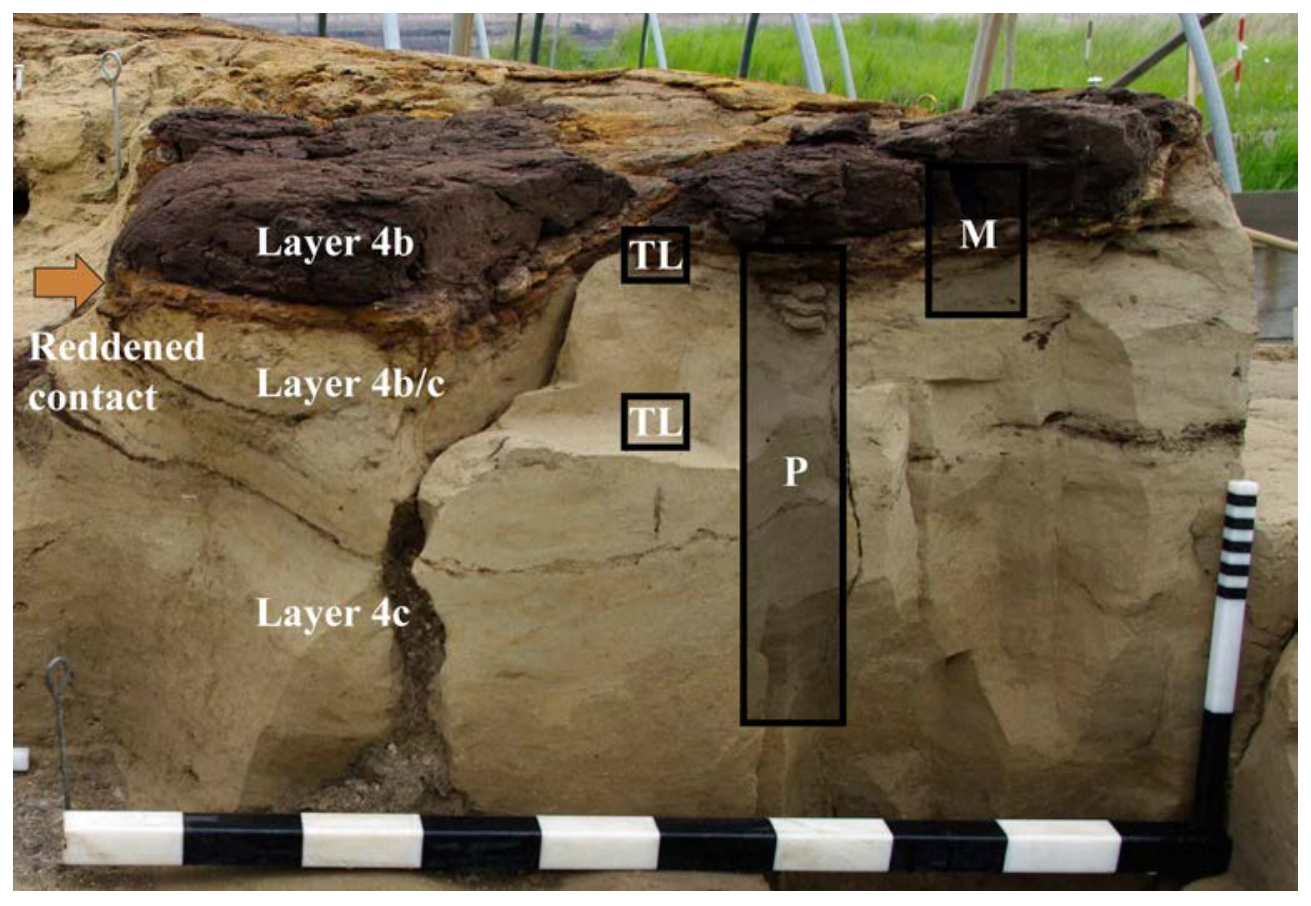




\section{Figure 7}
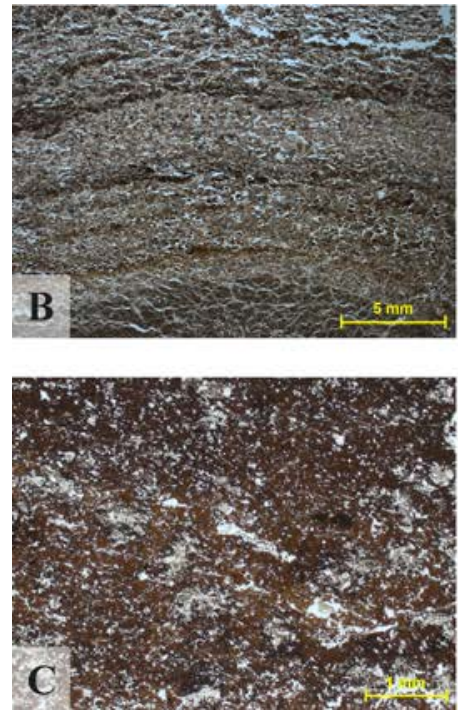
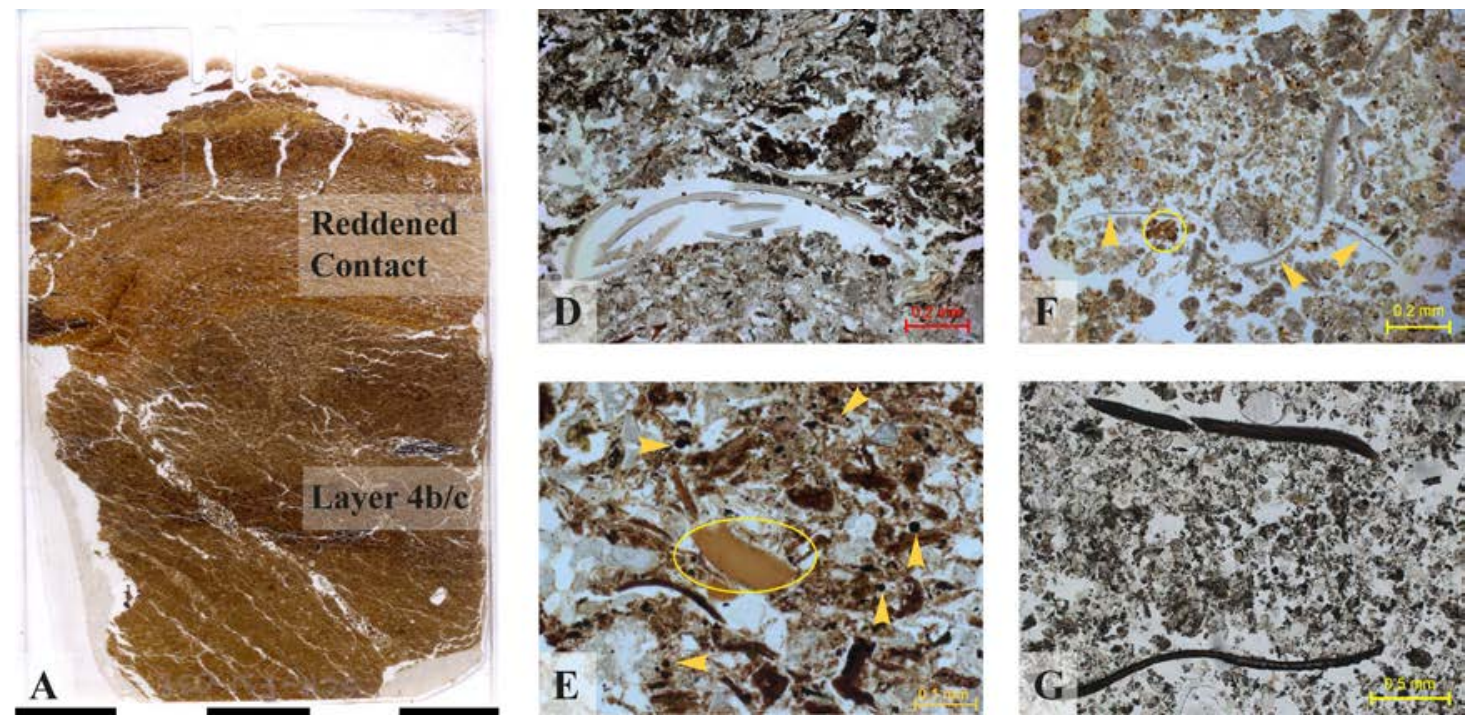
Figure 8

\author{
MPVGEOR - Evaluation Method: Coal random (1 Stnd)
}

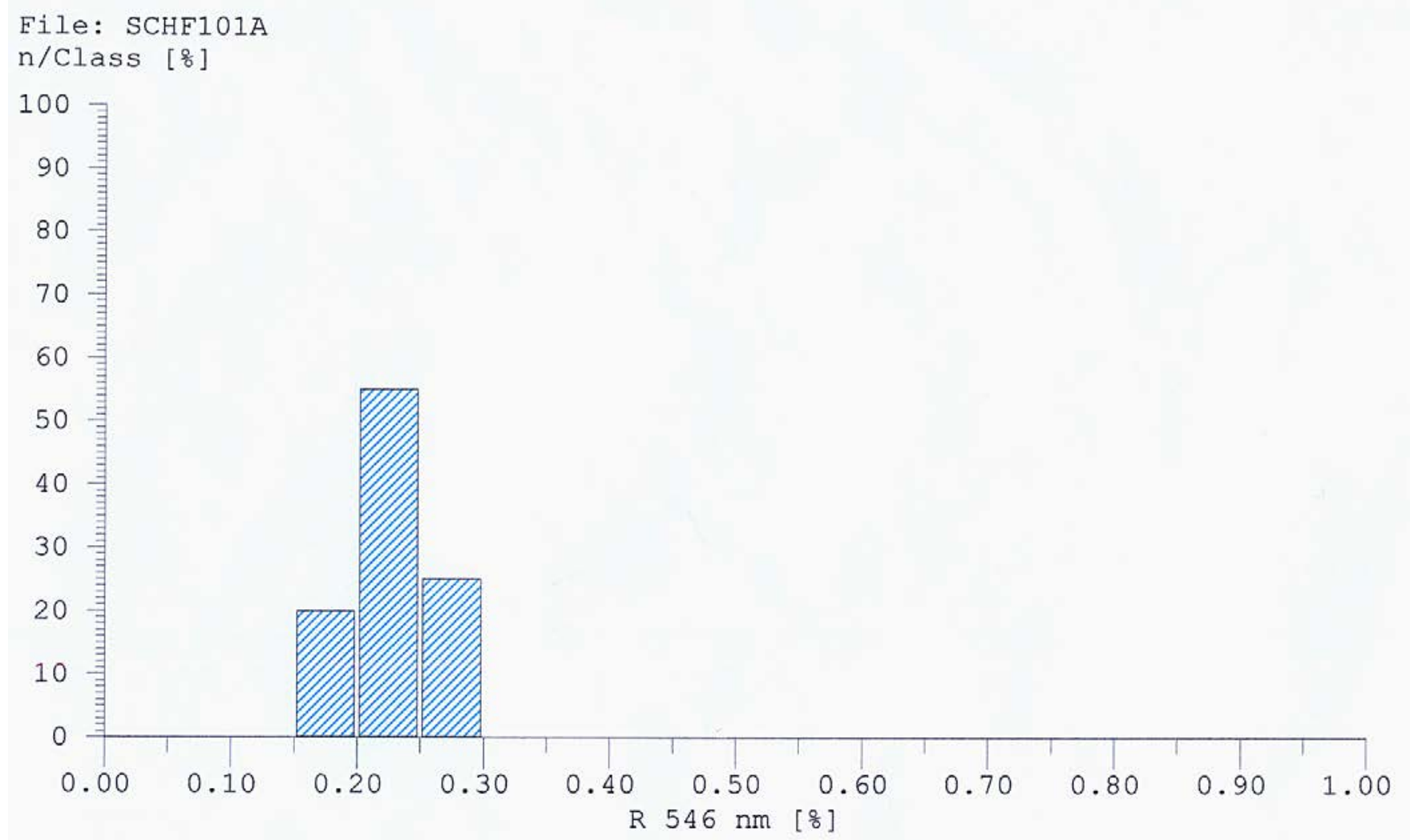

File: SCHF101A

Reflectivity [\%]

\begin{tabular}{rr} 
Lambda : & $546 \mathrm{~nm}$ \\
\hline Minimum : & 0.177 \\
Maximum : & 0.282 \\
Mean Value : & 0.225 \\
Standard-Dev. : & 0.030 \\
Variance : & 0.001 \\
Rel.Var.-Coeff. : & $3.06 \%$ \\
Total N : & 20
\end{tabular}


Figure 9

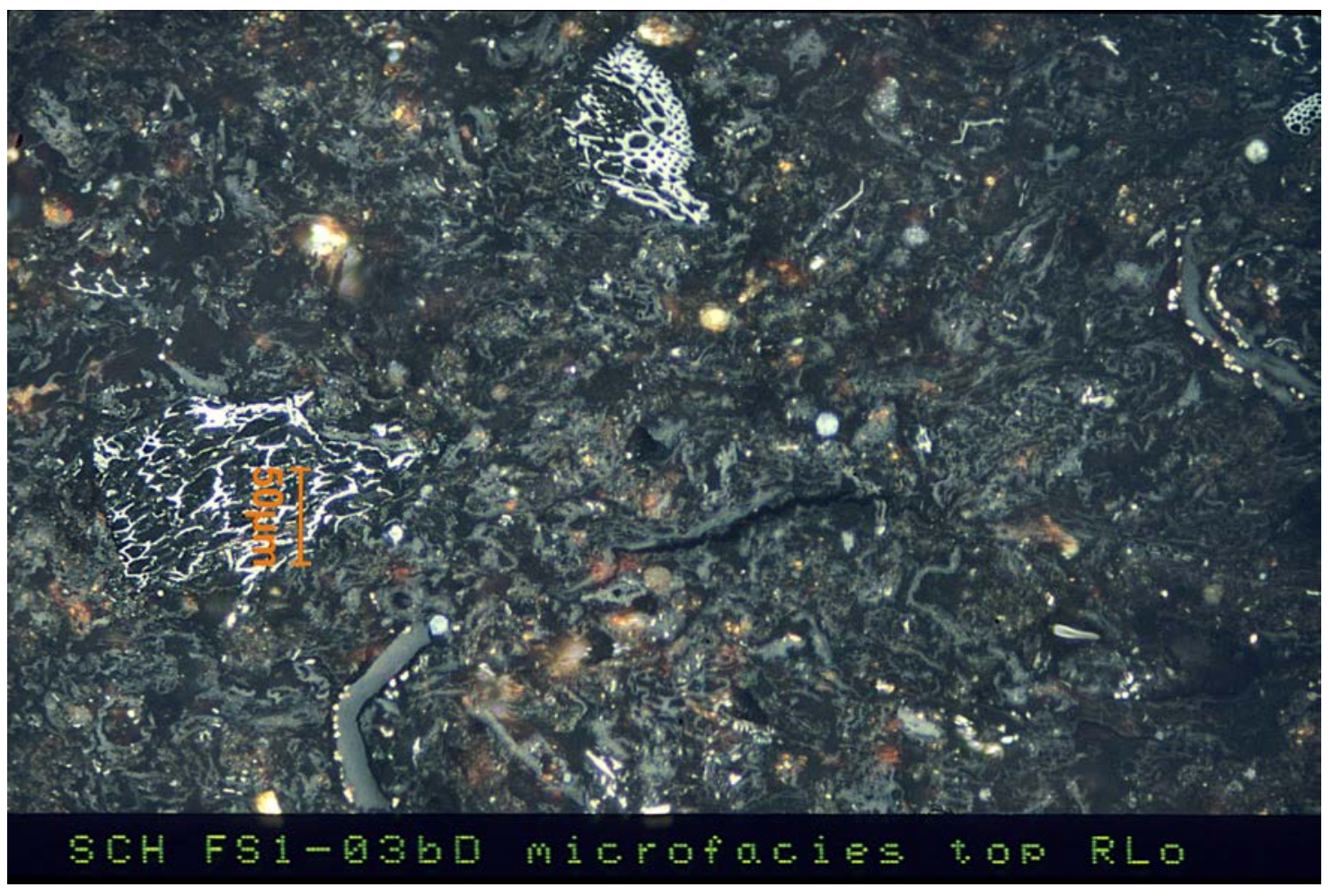




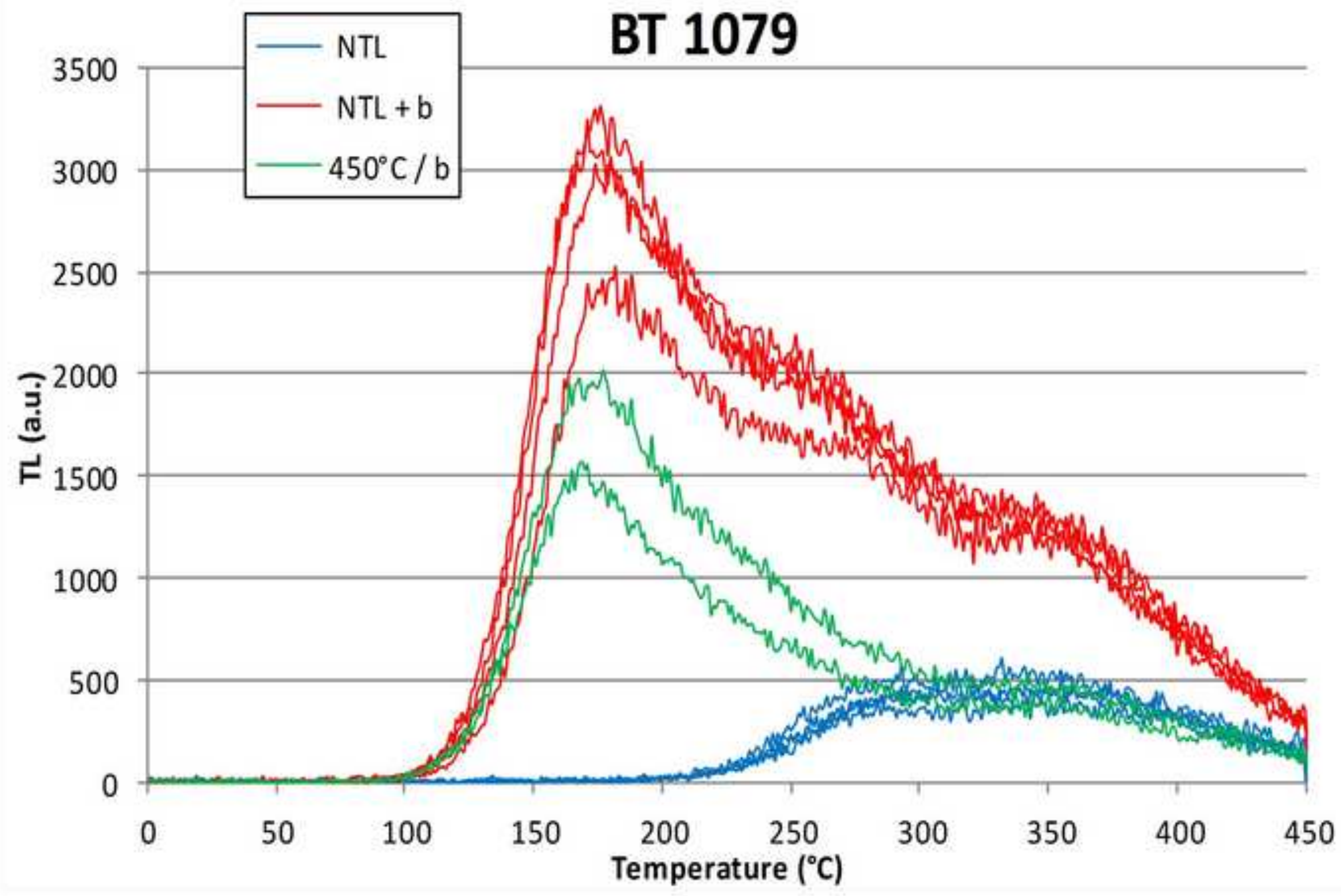




\section{Heating Plateau BT 1079}

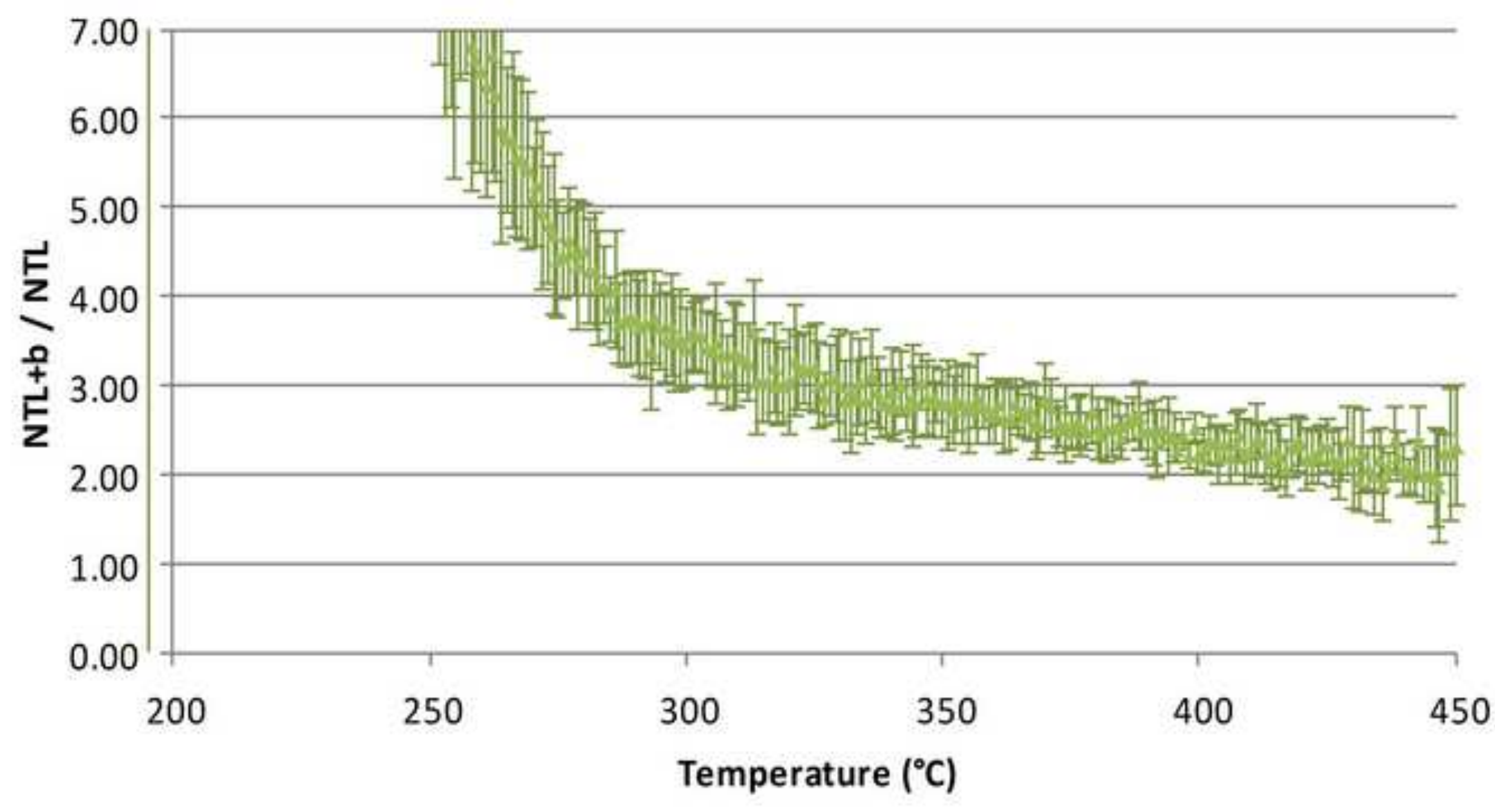









\section{Heating Plateau BT 1077}






\section{BT 1080}

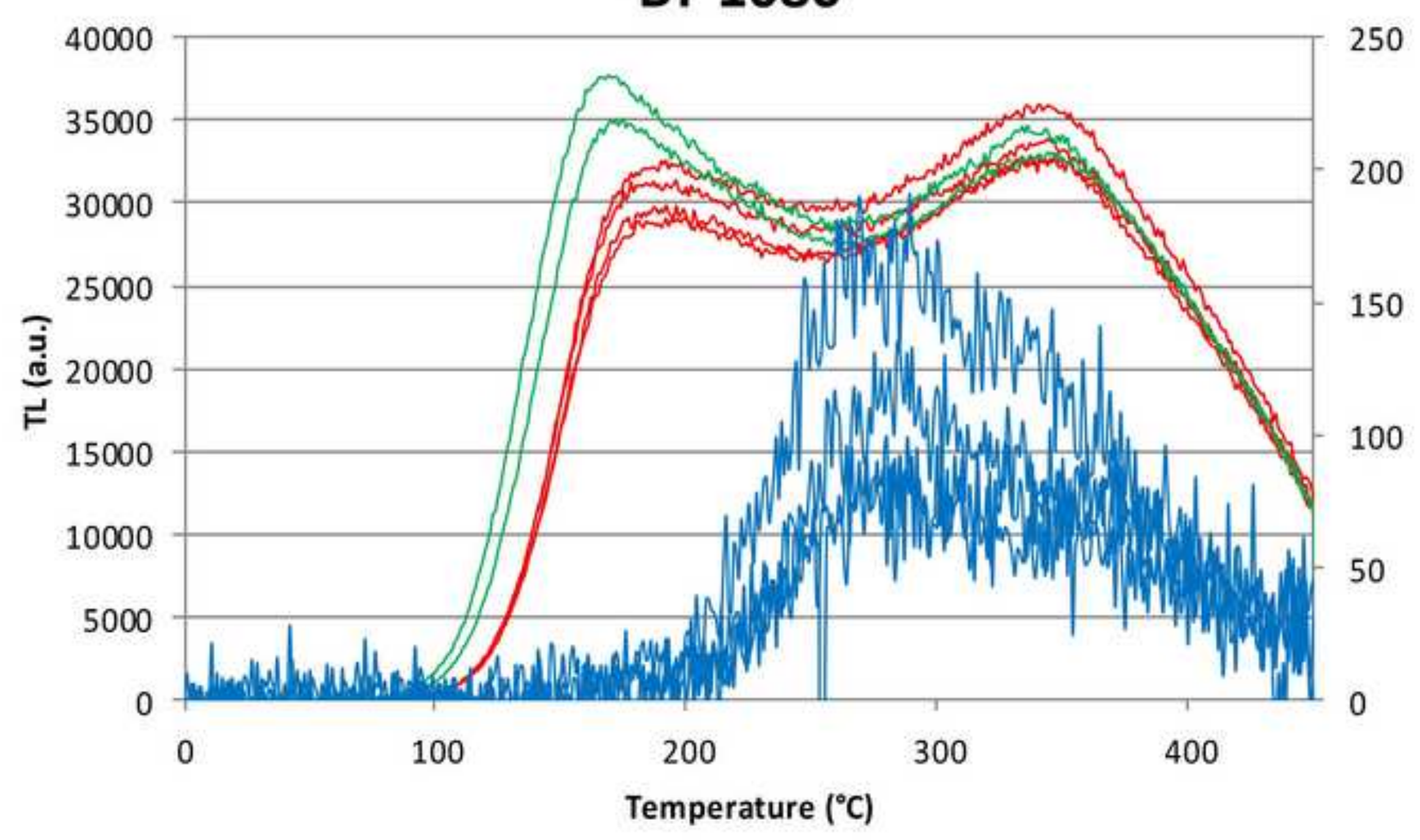




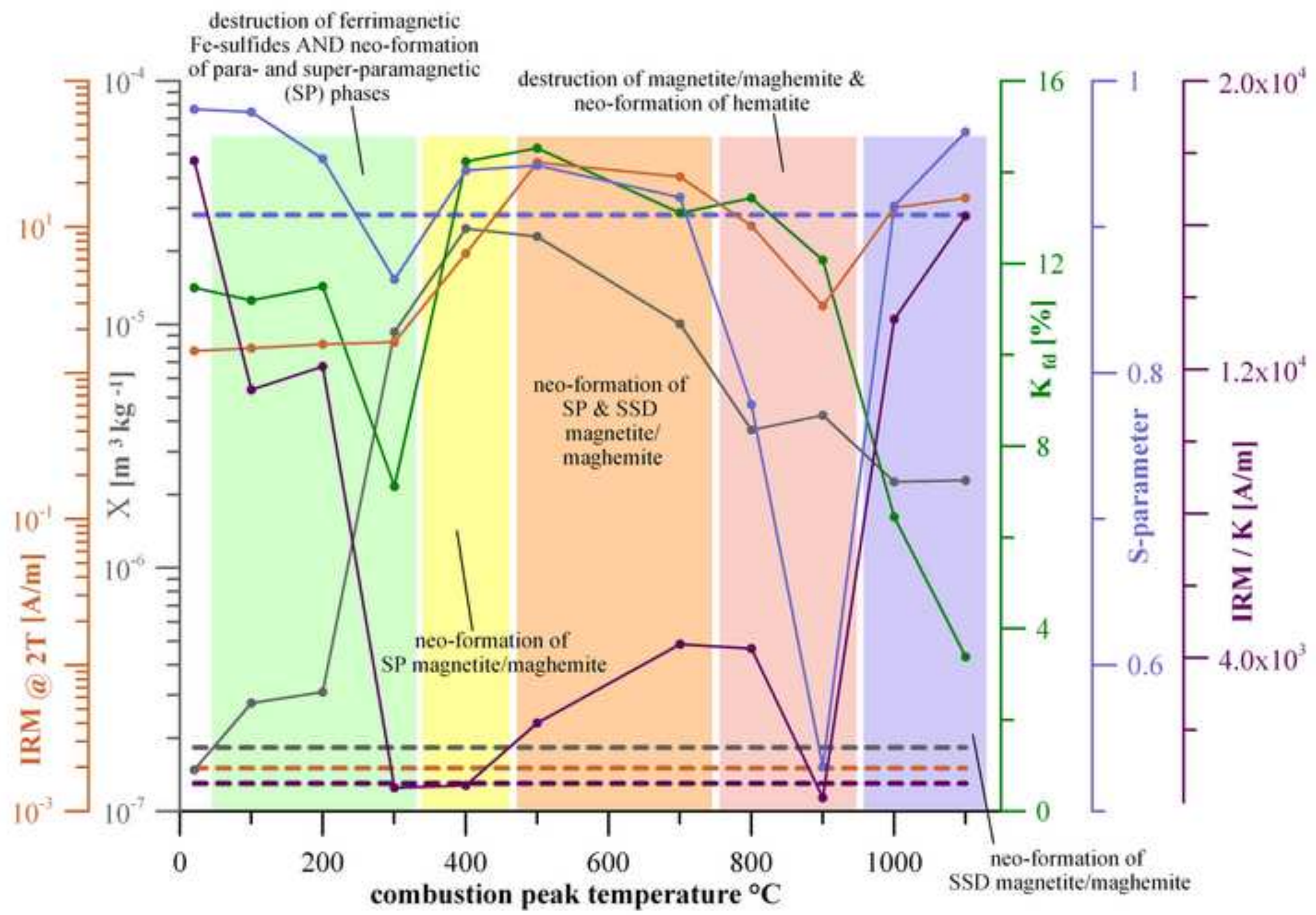




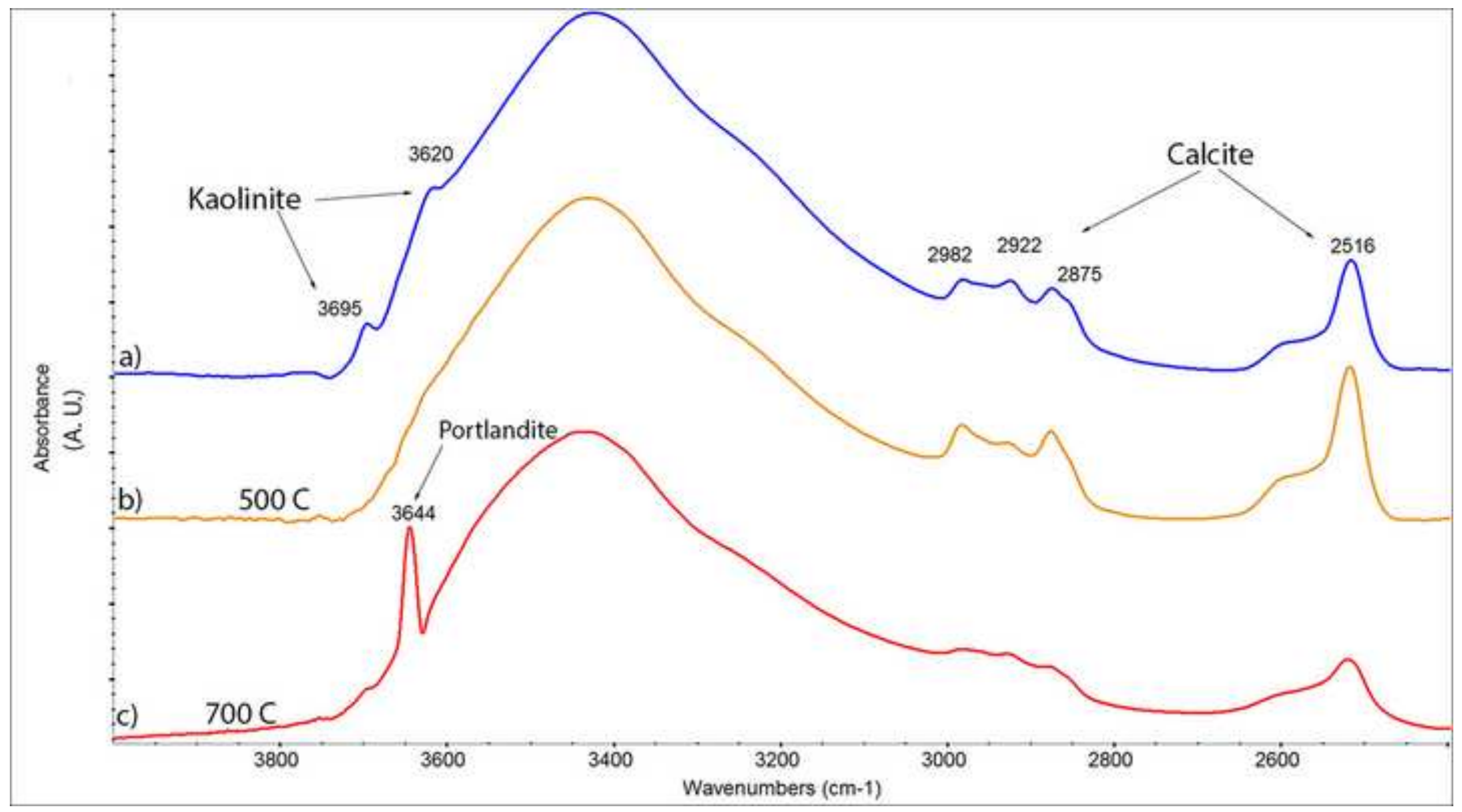




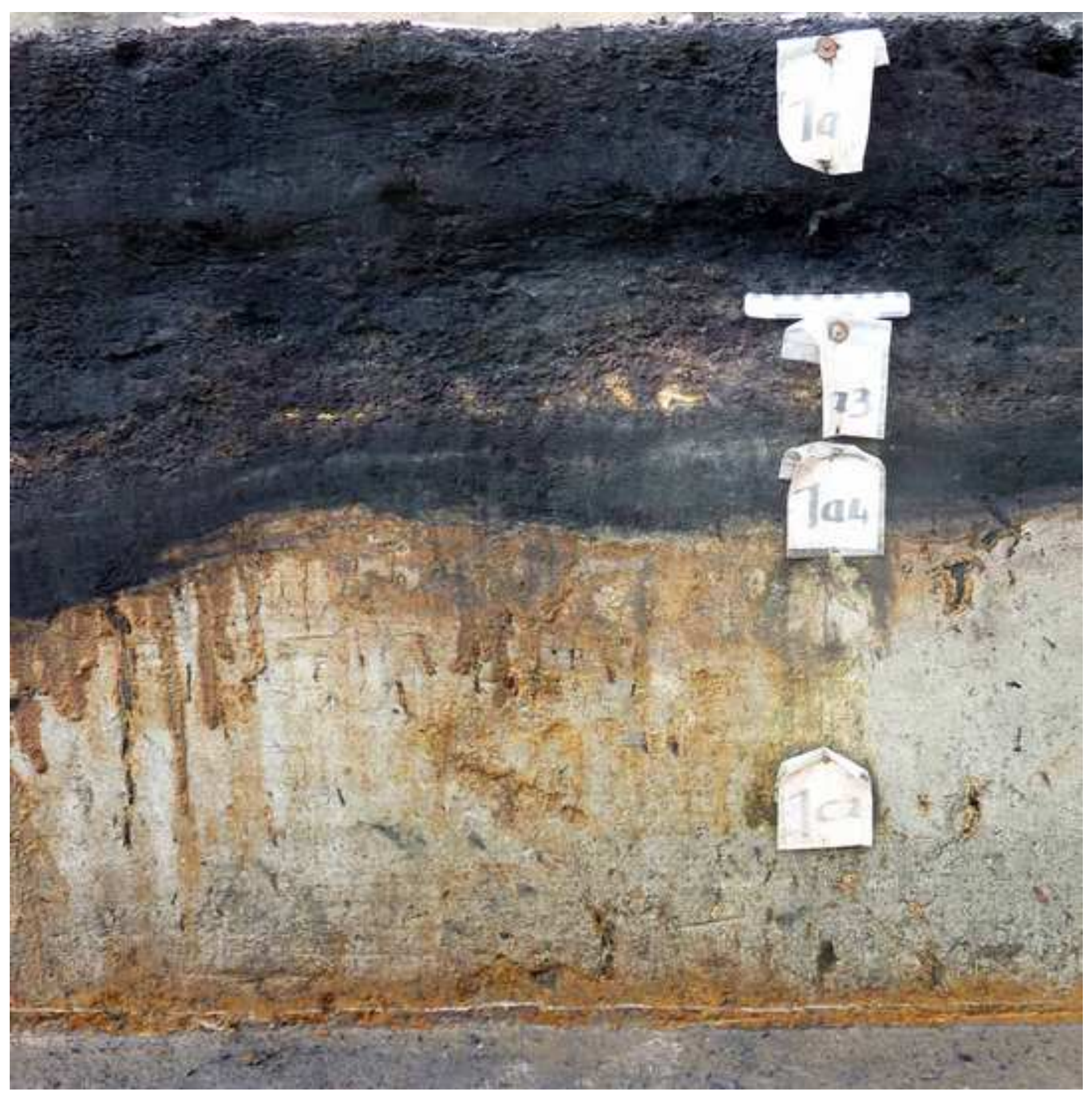

Figure 13

\section{Figure 13} 3

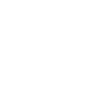




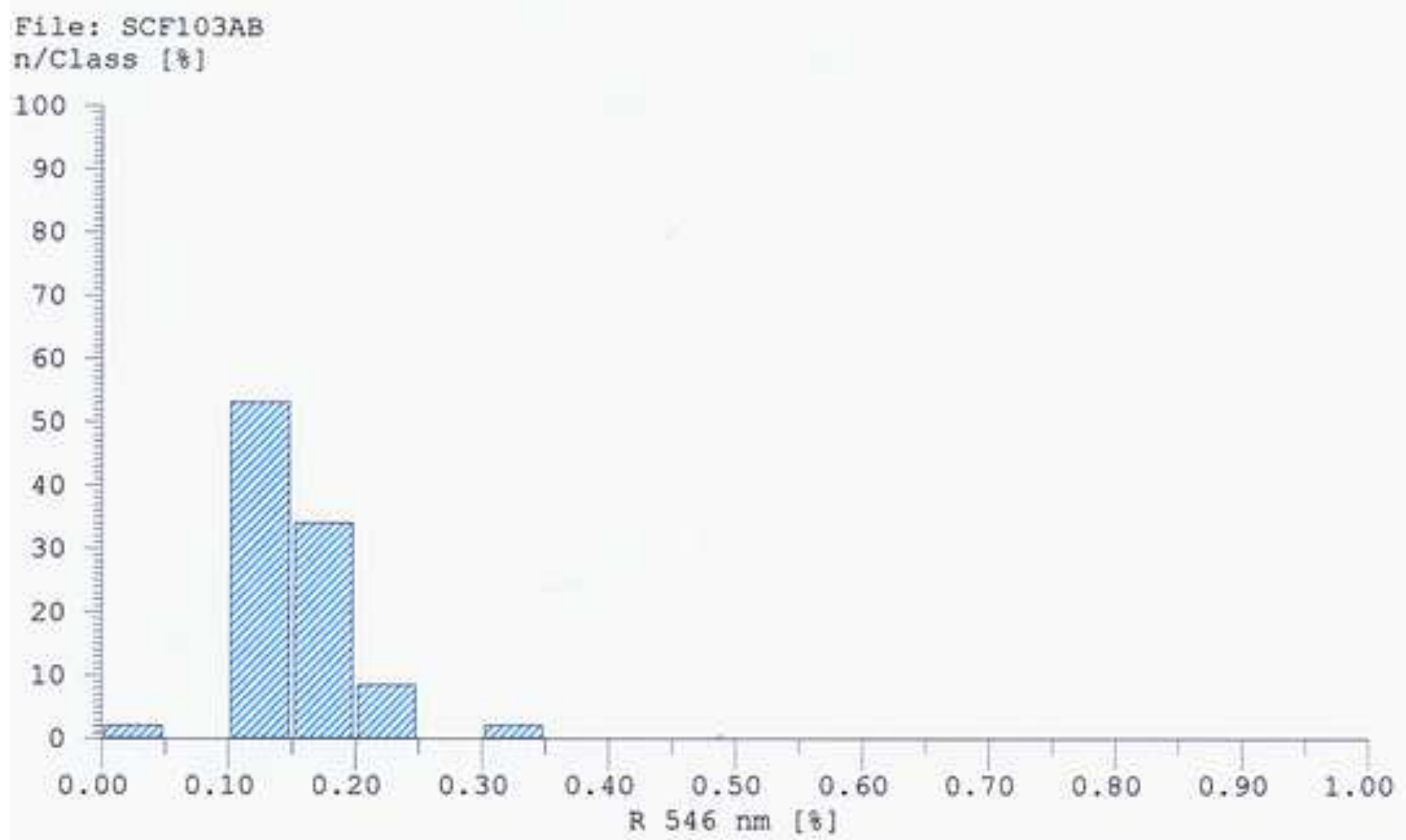

File: SCF103AB

Reflectivity [\%]

Lambda : $546 \mathrm{~nm}$

$\begin{aligned} \text { Minimum : } & 0.039 \\ \text { Maximum : } & 0.314 \\ \text { Mean Value : } & 0.156 \\ \text { Standard-Dev. : } & 0.042 \\ \text { Variance : } & 0.002 \\ \text { Rel.Var.-Coeff. : } & 3.998 \\ \text { Total N : } & 47\end{aligned}$


File: SCH13I13

$n /$ Class [t]

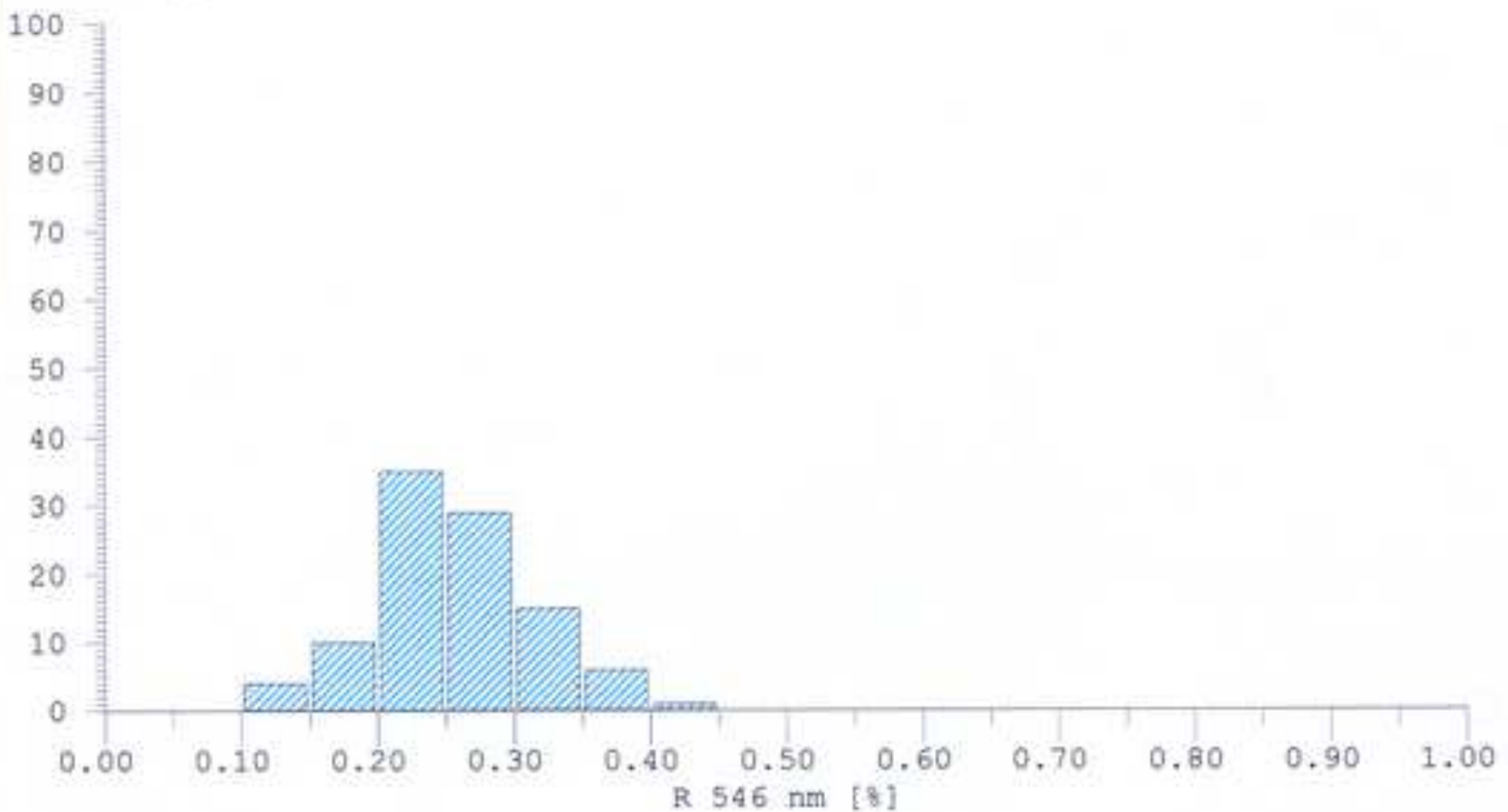

File: SCH13II3

Reflectivity [?]

\begin{tabular}{rr} 
Lambda : & $546 \mathrm{~nm}$ \\
\hline Minimum : & 0.100 \\
Maximum : & 0.428 \\
Mean Value : & 0.255 \\
Standard-Dev. : & 0.059 \\
Variance : & 0.003 \\
Re1.Var.-Coeff.: & 2.338 \\
Total N : & 100
\end{tabular}






File: $\$ 199212$

Reflectivity [8]

Lambda : $546 \mathrm{~nm}$

Minimum : $\quad 0.115$

Maximum : $\quad 0.167$

Mean Value : $\quad 0.138$

Standard-Dev. : $\quad 0.011$

Variance : $\quad 0.000$

Rel.Var,-Coeff. : $1.14 \%$

Total N : 50 
Table 1. Overview of the Middle Pleistocene purported evidence for anthropogenic fire at Schöningen ${ }^{\mathrm{a}}$

\begin{tabular}{|c|c|c|c|c|c|c|c|}
\hline Site/locality & $\begin{array}{l}\text { Archaeological } \\
\text { remains }\end{array}$ & Fire evidence & $\begin{array}{l}\text { Publication of fire } \\
\text { evidence }\end{array}$ & References of fire evidence & Performed analysis & Results & $\begin{array}{l}\text { Interpretation: } \\
\text { anthropogenic fire }\end{array}$ \\
\hline Schöningen 13 I & Lithics, bone remains & $\begin{array}{l}\text { Burnt flint -natural } \\
\text { pieces }\end{array}$ & $\begin{array}{l}\text { Richter, 1998, 2007, } \\
\text { Richter and Thieme, } \\
2012\end{array}$ & $\begin{array}{l}\text { Alperson-Afil and Goren-Inbar, } \\
\text { 2006; Wrangham, 2009; } \\
\text { Roebroeks and Villa, 2011a }\end{array}$ & Thermoluminescence & Burnt & $\begin{array}{l}\text { Fire use: unknown } \\
\text { Fire control: no } \\
\text { Fire making: no }\end{array}$ \\
\hline $\begin{array}{l}\text { Schöningen } 13 \text { II- } \\
1\end{array}$ & $\begin{array}{l}\text { Bone remains with } \\
\text { cutmarks }\end{array}$ & Burnt wood & Thieme, 2002 & & & & \\
\hline $\begin{array}{l}\text { Schöningen } 13 \text { II- } \\
2 / 3\end{array}$ & $\begin{array}{l}\text { Bone remains, lithics, } \\
\text { one wood artefact }\end{array}$ & Black sediment & - & - & Organic petrology & $\begin{array}{l}\text { Not } \\
\text { burnt }\end{array}$ & - \\
\hline $\begin{array}{l}\text { Schöningen } 13 \text { II- } \\
2 \text { Berme }\end{array}$ & $\begin{array}{l}\text { Bone remains, two } \\
\text { lithics }\end{array}$ & $\begin{array}{l}\text { Accumulation of } \\
\text { burnt wood (termed } \\
\text { hearth) }\end{array}$ & Thieme, 2007d & - & No & - & - \\
\hline \multirow[t]{4}{*}{$\begin{array}{l}\text { Schöningen } 13 \text { II- } \\
4\end{array}$} & $\begin{array}{l}\text { Lithics, wooden tools, } \\
\text { bone remains with } \\
\text { cutmarks }\end{array}$ & Hearths & $\begin{array}{l}\text { Thieme, 1997, 1999, } \\
\text { 2005, 2007b; Schiegl } \\
\text { and Thieme, } 2007\end{array}$ & $\begin{array}{l}\text { Gaudzinski and Roebroeks, 2000; } \\
\text { Alperson-Afil and Goren-Inbar, } \\
\text { 2006; Preece et al., 2006; Klein, } \\
\text { 2009; Wrangham, 2009; } \\
\text { Roebroeks and Villa, 2011a }\end{array}$ & $\begin{array}{l}\text { Micromorphology, } \\
\text { FTIR, mFTIR, organic } \\
\text { petrology, } \\
\text { thermoluminescence, } \\
\text { mineral magnetic } \\
\text { parameters }\end{array}$ & $\begin{array}{l}\text { Not } \\
\text { burnt }\end{array}$ & - \\
\hline & $\begin{array}{l}\text { Lithics, wooden tools, } \\
\text { bone remains with } \\
\text { cutmarks }\end{array}$ & Burnt bone & - & Voormolen, 2008 & - & - & - \\
\hline & $\begin{array}{l}\text { Lithics, wooden tools, } \\
\text { bone remains with } \\
\text { cutmarks }\end{array}$ & $\begin{array}{l}\text { charred wood- } \\
\text { roasting stick } \\
\text { (Bratspieß) }\end{array}$ & $\begin{array}{l}\text { Thieme, 1997, 1999, } \\
\text { 2005, 2007a }\end{array}$ & $\begin{array}{l}\text { Preece et al., 2006; Wrangham, } \\
\text { 2009; Roebroeks and Villa, 2011a }\end{array}$ & No & - & - \\
\hline & $\begin{array}{l}\text { Lithics, wooden tools, } \\
\text { bone remains with } \\
\text { cutmarks }\end{array}$ & $\begin{array}{l}\text { Burnt wood - Fire- } \\
\text { hardened spears }\end{array}$ & - & $\begin{array}{l}\text { Rice, 2007; Berna and Goldberg, } \\
\text { 2008; Coolidge and Wynn, 2009; } \\
\text { Alperson-Afil et al., 2010; } \\
\text { Weiner, } 2010\end{array}$ & - & - & - \\
\hline $\begin{array}{l}\text { Schöningen } 12 \text { A } \\
\text { - find horizon } 2\end{array}$ & - & $\begin{array}{l}\text { Accumulation of } \\
\text { burnt wood (termed } \\
\text { hearth) }\end{array}$ & $\begin{array}{l}\text { Thieme and Maier, } \\
1995\end{array}$ & - & No & - & - \\
\hline $\begin{array}{l}\text { Schöningen } 12 \text { B- } \\
\text { find horizon } 2\end{array}$ & Bone remains, lithics & Burnt wood & $\begin{array}{l}\text { Mania, 1995; Thieme, } \\
\text { 2007c }\end{array}$ & - & Organic petrology & $\begin{array}{l}\text { Not } \\
\text { burnt }\end{array}$ & - \\
\hline
\end{tabular}


${ }^{a}$ Note that only in one instance (burnt lithics 13 I) were analyses able to confirm the burnt state of the material, while at the same time an anthropogenic involvement is doubtful. 
Table 2. Sample list of all block and bulk samples, their location, and employed method ${ }^{\mathrm{a}}$

\begin{tabular}{|c|c|c|c|c|c|c|c|}
\hline Site & Sample No/ID & Sample type & Square & Z-value & Feature & Layer & Employed method \\
\hline \multirow[t]{13}{*}{ Schöningen 13 II-4 } & Schö 13 II-4 Sch FS1 1 & Sediment block sample & $683 / 21$ & $102.44-102.56$ & hearth 1 & $4 b-$ red layer-4c & $\begin{array}{l}\text { Micromorphology/mFTIR/ } \\
\text { Organic Petrology }\end{array}$ \\
\hline & Schö 13 II-4 Sch FS1 2 & Sediment block sample & $682 / 21$ & $102.29-102.40$ & hearth 1 & $4 b-$ red layer- $4 c$ & Micromorphology/mFTIR \\
\hline & Schö 13 II-4 Sch FS1 3 & Sediment block sample & $683 / 21$ & $102.54-102.80$ & hearth 1 & $4 b-$ red layer- $4 c$ & $\begin{array}{l}\text { Micromorphology/mFTIR/ } \\
\text { Organic Petrology }\end{array}$ \\
\hline & Schö 13 II-4 Sch FS1 4 & Sediment block sample & $682 / 21$ & $102.37-102.42$ & hearth 1 & $4 \mathrm{c}$ & Micromorphology/mFTIR \\
\hline & $\begin{array}{l}\text { Schö } 13 \text { II FS1 2010/21.1 } \\
\text { BT } 1079\end{array}$ & Sediment block sample & $683 / 22$ & $102.61-102.05$ & hearth 1 & $4 \mathrm{c}$ & Thermoluminescence \\
\hline & $\begin{array}{l}\text { Schö } 13 \text { II-4 FS } 1 \\
2010 / 22.1\end{array}$ & Sediment bulk sample & $683 / 22$ & $\begin{array}{l}102.05- \\
102.62\end{array}$ & hearth 1 & $4 \mathrm{c}$ & $\begin{array}{l}\text { Mineral Magnetic } \\
\text { Parameters }\end{array}$ \\
\hline & Schö 13II-4 FS 1 2010/16 & Sediment bulk sample & $682 / 22$ & 102.54 & hearth 1 & $4 \mathrm{c}$ & $\begin{array}{l}\text { Mineral Magnetic } \\
\text { Parameters }\end{array}$ \\
\hline & Schö 13 II-4 2010/29 & Sediment bulk sample & $693 / 14$ & 102.42 & hearth 2 & $4 b-$ red layer- $4 c$ & FTIR \\
\hline & Schö 13 II-4 2010/30 & Sediment bulk sample & $693 / 13$ & 102.46 & hearth 2 & $4 b-$ red layer- $4 c$ & Micromorphology /FTIR \\
\hline & Schö 13 II-4 2011/5 & Sediment block sample & $694 / 6$ & 102.73 & hearth 3 & $4 c-$ red layer- $4 \mathrm{c}$ & Micromorphology \\
\hline & Schö 13 II-4 2011/08 & Sediment block sample & $695 / 7$ & 103.00 & hearth 3 & $4 b-$ red layer- $4 c$ & Micromorphology \\
\hline & Schö 13 II-4 2011/01 & Sediment block sample & $695 / 8$ & $102.99-102.74$ & hearth 3 & $4 b-$ red layer- $4 c$ & Micromorphology \\
\hline & Schö 13 II-4 2010/23 & Sediment block sample & $704 / 9$ & $101.65-102.05$ & hearth 4 & $4 b-$ red layer- $4 c$ & Micromorphology/FTIR \\
\hline
\end{tabular}




\begin{tabular}{|c|c|c|c|c|c|c|c|}
\hline & Schö 13 II-4 2010/24 & Sediment bulk sample & $705 / 9$ & $101.51-102.15$ & hearth 4 & $4 b-$ red layer- $4 c$ & Micromorphology/FTIR \\
\hline & Schö 13 II-4 FS1 5 & Sediment block sample & $684 / 22$ & 102.17 & & $4 c$ & Micromorphology/mFTIR \\
\hline & Schö 13 II-4 2003/3.1 & Sediment block sample & $719 /-995$ & 102,16 & & $4 b-4 c$ & Micromorphology \\
\hline & $\begin{array}{l}\text { Schö 13II-4 BT-2011/25 } \\
\text { BT } 1077\end{array}$ & Sediment block sample & $776 /-949$ & 101.26 & & $4 \mathrm{c}$ & Thermoluminescence \\
\hline & Schö 13 II-4 BrEx 4b/c & Sediment bulk sample & & & $\begin{array}{l}\text { off site } \\
\text { marl }\end{array}$ & $4 \mathrm{~b} / \mathrm{c}$ & Heating Experiment \\
\hline & Schö 13 II-4 BrEx 4b & Sediment bulk sample & & & $\begin{array}{l}\text { off site } \\
\text { marl }\end{array}$ & $4 b$ & Heating Experiment \\
\hline Schöningen 13 II-3/2 & $\begin{array}{l}\text { Schöningen } 13 \text { II-3/2 } \\
2010 / 35\end{array}$ & sediment bulk sample & $681 / 21$ & 98.95 & & $2 \mathrm{a}$ & Organic Petrology \\
\hline Schöningen 13 II-3/2 & $\begin{array}{l}\text { Schöningen } 13 \text { II-3/2 } \\
2010 / 36\end{array}$ & sediment bulk sample & $682 / 21$ & 98.95 & & $2 \mathrm{a}$ & Organic Petrology \\
\hline Schöningen 12 B & ID13325 & Wood and sediment & $7 / 10$ & Not specified & & Not specified & Organic Petrology \\
\hline
\end{tabular}

${ }^{a}$ Note that some block samples were analyzed by micromorphology, organic petrology, and FTIR.

${ }^{\mathrm{b}} \mathrm{Z}$-value relate to block sample and not the actual sample. 
Table 3. Micromorphological description of layers $4 \mathrm{~b}$ and layer $4 \mathrm{~b} / \mathrm{c}$ at the four hearths and the control sample (Schö 13 II-4 2003/3.1)

\begin{tabular}{|c|c|c|c|c|c|}
\hline Sample No. & Layer & $\begin{array}{l}\text { Microstructure, aggregates, } \\
\text { voids, and ratio coarse to fine } \\
\text { fraction }\end{array}$ & Fine fraction ${ }^{b}$ & Coarse fraction $^{b}$ & Comments \\
\hline $\begin{array}{l}\text { Schö } 13 \text { II-4 } \\
\text { sediment } \\
\text { hearth 1-4 }\end{array}$ & $4 \mathrm{~b}$ & $\begin{array}{l}\text { Homogenous, locally laminated; } \\
\text { elongated plant tissue residues } \\
\text { with a tendency for horizontal } \\
\text { alignment, large fractures, lens } \\
\text { structure in one TS }\end{array}$ & $\begin{array}{l}\text { Clay and amorphous } \\
\text { organic fine material }\end{array}$ & $\begin{array}{l}\text { Plant issue residues and cells ( } 0.1 \text { to } 0.002 \mathrm{~mm} \text {, } \\
\text { but predominantly } \sim 0.5 \text { to } 0.1 \mathrm{~mm} \text {; fragmented, } \\
\text { light brown to brown in color), quartz (rounded, } \\
\text { fine sand to silt sized), mica, gypsum, } \\
\text { framboidal pyrite, sponge spicules, diatoms, } \\
\text { very few rounded charcoal particles }\end{array}$ & 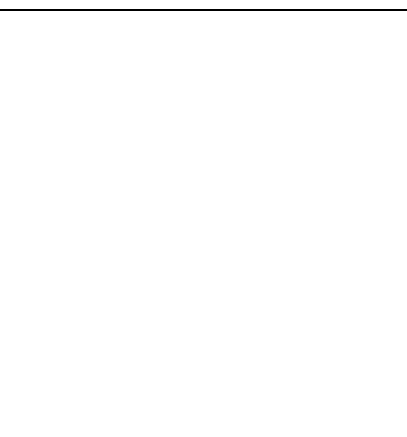 \\
\hline $\begin{array}{l}\text { Schö } 13 \text { II-4 } \\
\text { sediment } \\
\text { hearth 1-4 }\end{array}$ & $4 \mathrm{~b} / \mathrm{c}$ & $\begin{array}{l}\text { Water escape structures } \\
\text { elongated plant tissue residues } \\
\text { with a tendency for horizontal } \\
\text { alignment, simple packing voids, } \\
\text { some large fractures }\end{array}$ & $\begin{array}{l}\text { Dominantly micritic to } \\
\text { rarely rhombohedral } \\
\text { calcite to clayey and } \\
\text { amorphous organic fine } \\
\text { material }\end{array}$ & $\begin{array}{l}\text { Plant tissue residues and cells ( } 0.02 \text { to } 0.001 \\
\mathrm{~mm} \text {, but predominantly around } 0.5 \text { to } 0.1 \mathrm{~mm} \text {, } \\
\text { fragmented, light brown to brown in color), } \\
\text { quartz (rounded, fine sand to silt sized), } \\
\text { framboidal pyrite, ostracods and mollusk } \\
\text { fragments, charophyte internodia and } \\
\text { gyrogonites, gypsum sponge, spicules, diatoms, } \\
\text { bone fragments (angular, } \sim 0.5 \mathrm{~mm} \text { ) }\end{array}$ & $\begin{array}{l}\text { Contact with unit } 4 \mathrm{~b} \text { clear and } \\
\text { with intense iron precipitation } \\
\text { Diffuse iron precipitation }\end{array}$ \\
\hline
\end{tabular}




\begin{tabular}{|c|c|c|c|c|c|}
\hline Schö 13 II-4 & $4 \mathrm{c}$ & Homogenous, elongated plant & Dominantly micritic to & Quartz (rounded, fine sand to silt sized), plant & Contact with unit $4 \mathrm{~b} / \mathrm{c}$ gradual \\
\hline sediment & & tissues residues with tendency for & rarely rhombohedral & tissue residues and cells $(0.01$ to $0.2 \mathrm{~mm}$, & Diffuse iron precipitation \\
\hline \multirow[t]{4}{*}{ hearth 1,4} & & horizontal alignment, simple & calcite to slightly clayey & fragmented, light brown to brown in color) & \\
\hline & & packing voids, few larger & & framboidal pyrite, gypsum, ostracod and & \\
\hline & & fractures & & mollusk fragments, charophyte internodia and & \\
\hline & & & & gyrogonites, diatoms sponge spicules & \\
\hline Schö 13 II-4 & $4 \mathrm{~b}$ & Elongated plant tissue residue & Clay and amorphous & Plant tissue residues and cells (around 0.5 to 0.1 & Fracture and fissure related to \\
\hline \multirow[t]{4}{*}{$2003 / 3.1$} & & with a tendency for horizontal & organic fine material & $\mathrm{mm}$; fragmented, light brown to brown in & recent freezing and defrosting \\
\hline & & alignment, large vertical fractures & & color), gypsum, quartz (rounded, fine sand to sit & \\
\hline & & slightly fissural & & sized), mica, framboidal pyrite, diatoms, sponge & \\
\hline & & & & spicules & \\
\hline Schö 13 II-4 & $4 \mathrm{~b} / \mathrm{c}$ & Elongated plant tissue residue & Dominantly micritic to & Plant tissue residues and cells $(0.5$ to $0.1 \mathrm{~mm}$, & Contact with $4 \mathrm{~b} / \mathrm{c}$ clear but \\
\hline \multirow[t]{6}{*}{$2003 / 3.1$} & & with a tendency for horizontal & rarely rhombohedral & fragmented, light brown to brown in color), & fractured \\
\hline & & alignment, simple packing voids, & calcite to clay and & quartz (rounded, fine sand to silt sized), & Fractures related to recent \\
\hline & & some large fractures & amorphous organic fine & framboidal pyrite, ostracods and mollusk & freezing and defrosting \\
\hline & & & material & fragments, charophyte internodia and & \\
\hline & & & & gyrogonites, gypsum, sponge spicules, diatoms, & \\
\hline & & & & bone fragments (angular, $\sim 0.5 \mathrm{~mm}$ ) & \\
\hline
\end{tabular}

\footnotetext{
${ }^{\mathrm{a}}$ The variation between the four hearths is insignificant and they are therefore described as one.
}

${ }^{\mathrm{b}}$ Limit fine to coarse fraction at $10 \mu \mathrm{m}$. 
Table 4. Optical properties of plant tissues of the liptinite group (spores, pollen, algae, bark- or cork-derived tissue) in the samples Schö 13 II-4 FS $11 \mathrm{a}$ and $1 \mathrm{~b}$ and $3 a$ and $3 b$

\begin{tabular}{|c|c|c|c|c|c|c|c|c|c|c|c|}
\hline \multicolumn{6}{|c|}{ Schö 13II-4 FS1 1a\&b } & \multicolumn{6}{|c|}{ Schö 13II-4 FS1 3a\&b } \\
\hline \multirow{2}{*}{$\begin{array}{l}\text { Lithological } \\
\text { units and } \\
\text { thickness } \\
(\mathrm{cm})\end{array}$} & \multicolumn{3}{|c|}{ Huminite (telohuminite) reflectance } & \multicolumn{2}{|c|}{$\begin{array}{l}\text { Fluorescence properties of } \\
\text { organic particles }\end{array}$} & \multirow{2}{*}{$\begin{array}{l}\text { Lithological } \\
\text { units and } \\
\text { thickness } \\
(\mathrm{cm})\end{array}$} & \multicolumn{3}{|c|}{ Huminite (telohuminite) reflectance } & \multicolumn{2}{|c|}{$\begin{array}{l}\text { Fluorescence properties of } \\
\text { organic particles }\end{array}$} \\
\hline & $\begin{array}{c}\text { Mean } \\
\text { value } \% \mathrm{Rr}\end{array}$ & $\begin{array}{l}\text { Standard } \\
\text { deviation }\end{array}$ & $\begin{array}{c}\text { Number of } \\
\text { measurements }\end{array}$ & Huminite & Liptinite & & $\begin{array}{c}\text { Mean } \\
\text { value } \% \mathrm{Rr}\end{array}$ & $\begin{array}{l}\text { Standard } \\
\text { deviation }\end{array}$ & $\begin{array}{c}\text { Number of } \\
\text { measurements }\end{array}$ & $\begin{array}{l}\text { Lithological } \\
\text { units and } \\
\text { thickness } \\
(\mathrm{cm})\end{array}$ & $\begin{array}{l}\text { Huminite } \\
\text { (telohuminite) } \\
\text { reflectance }\end{array}$ \\
\hline $\begin{array}{c}\mathbf{4 b} \\
>1.8\end{array}$ & 0.21 & 0.039 & 100 & $\begin{array}{c}\text { non- } \\
\text { fluorescing } \\
\text { to brown } \\
\text { fluorescing }\end{array}$ & $\begin{array}{c}\text { brightly } \\
\text { yellow and } \\
\text { green } \\
\text { fluorescing }\end{array}$ & $\begin{array}{c}\mathbf{4 b} \\
>6.3\end{array}$ & 0.17 & 0.028 & 100 & $\begin{array}{c}\text { non- } \\
\text { fluorescing } \\
\text { to brown } \\
\text { fluorescing }\end{array}$ & $\begin{array}{l}\text { yellow and } \\
\text { brightly green } \\
\text { fluorescing }\end{array}$ \\
\hline $\begin{array}{c}\text { Red } \\
\text { contact } \\
\text { upper part } \\
0.4-0.8\end{array}$ & 0.19 & 0.048 & 23 & $\begin{array}{c}\text { non- } \\
\text { fluorescing } \\
\text { to brown } \\
\text { fluorescing }\end{array}$ & $\begin{array}{l}\text { brightly } \\
\text { yellow and } \\
\text { brightly } \\
\text { green } \\
\text { fluorescing }\end{array}$ & $\begin{array}{c}\text { Red } \\
\text { contact } \\
\text { upper part } \\
0.3-0.5\end{array}$ & 0.13 & 0.031 & 40 & $\begin{array}{l}\text { non- } \\
\text { fluorescing } \\
\text { to brown } \\
\text { fluorescing }\end{array}$ & $\begin{array}{l}\text { yellow and } \\
\text { brightly green } \\
\text { fluorescing }\end{array}$ \\
\hline $\begin{array}{c}\text { Red } \\
\text { contact } \\
\text { lower part } \\
1.0-1.5\end{array}$ & 0.17 & 0.054 & 10 & $\begin{array}{c}\text { non- } \\
\text { fluorescing } \\
\text { to brown } \\
\text { fluorescing }\end{array}$ & $\begin{array}{l}\text { yellow and } \\
\text { brightly } \\
\text { green } \\
\text { fluorescing }\end{array}$ & $\begin{array}{c}\text { Red } \\
\text { contact } \\
\text { lower part } \\
2.0-2.5\end{array}$ & 0.15 & 0.042 & 47 & $\begin{array}{l}\text { non- } \\
\text { fluorescing } \\
\text { to brown } \\
\text { fluorescing }\end{array}$ & $\begin{array}{l}\text { yellow and } \\
\text { green } \\
\text { fluorescing }\end{array}$ \\
\hline $\begin{aligned} & \mathbf{4 c} \\
> & 5.8\end{aligned}$ & 0.22 & 0.030 & 20 & $\begin{array}{l}\text { non- } \\
\text { fluorescing } \\
\text { to brown } \\
\text { fluorescing }\end{array}$ & $\begin{array}{l}\text { yellow and } \\
\text { green } \\
\text { fluorescing }\end{array}$ & $\begin{array}{c}\mathbf{4 c} \\
>1.3\end{array}$ & 0.15 & 0.051 & 34 & $\begin{array}{l}\text { non- } \\
\text { fluorescing } \\
\text { to brown } \\
\text { fluorescing }\end{array}$ & $\begin{array}{c}\text { brightly } \\
\text { yellow and } \\
\text { brightly green } \\
\text { fluorescing }\end{array}$ \\
\hline
\end{tabular}


Table 5. Overview of the results from the heating experiment ${ }^{\mathrm{a}}$

\begin{tabular}{|c|c|c|c|c|c|}
\hline Temperature & $\begin{array}{l}\text { Color } \\
\text { Macroscopic } \\
\text { (Munsell color } \\
\text { Chart) } \\
\end{array}$ & $\begin{array}{l}\text { Microstruct } \\
\text { ure }\end{array}$ & Components and their alterations & Red staining & $\begin{array}{l}\text { Mineral phases } \\
\text { (present after cooling-down to ambient } \\
\text { temperatures) }\end{array}$ \\
\hline $0^{\circ} \mathrm{C}$ & $\begin{array}{l}\text { 10YR 5/2 grayish } \\
\text { brown }\end{array}$ & Massive & $\begin{array}{l}\text { Shells, diatoms, quartz grains, plant } \\
\text { tissue residues and cells, bone, calcite, } \\
\text { clay }\end{array}$ & none & $\begin{array}{l}\text { Calcitic crystallitic b-fabric, } \\
\text { Kaolinite present }\end{array}$ \\
\hline up to $300^{\circ} \mathrm{C}$ & $\begin{array}{l}\text { 10YR 5/2 grayish } \\
\text { brown }\end{array}$ & - & $\begin{array}{l}\text { shells, diatoms, quartz grains, plant } \\
\text { tissue residues and cells, calcite, clay }\end{array}$ & - & $\begin{array}{l}\text { destruction of ferrimagnetic Fe- sulfides, neo- } \\
\text { formation of para- and super-paramagnetic } \\
\text { (SP) (Fe-oxide?) phases }\end{array}$ \\
\hline $400^{\circ} \mathrm{C}$ & $\begin{array}{l}\text { 10YR 5/2 grayish } \\
\text { brown }\end{array}$ & $\begin{array}{l}\text { Massive to } \\
\text { granular }\end{array}$ & $\begin{array}{l}\text { Shells grayish, diatoms and quartz } \\
\text { unaltered, charred plant tissue residues } \\
\text { and cells, calcite, clay }\end{array}$ & many dark red spots & $\begin{array}{l}\text { Calcitic crystallitic b-fabric, } \\
\text { no Kaolinite, neo-formation of SP Fe-oxide- } \\
\text { phases and of stable single domain (SSD) } \\
\text { magnetite/maghemite }\end{array}$ \\
\hline $500^{\circ} \mathrm{C}$ & $\begin{array}{l}10 \mathrm{YR} 6 / 3 \text { pale } \\
\text { brown }\end{array}$ & $\begin{array}{l}\text { Granular to } \\
\text { dense } \\
\text { massive }\end{array}$ & $\begin{array}{l}\text { Shells grayish, diatoms and quartz } \\
\text { unaltered, charred plant tissue residues } \\
\text { and cells, calcite, clay }\end{array}$ & many dark red spots & $\begin{array}{l}\text { Calcitic crystallitic b-fabric, magnetic phases } \\
\text { as above, } \\
\text { no Kaolinite }\end{array}$ \\
\hline $700^{\circ} \mathrm{C}$ & $\begin{array}{l}7.5 \mathrm{YR} 7 / 4-6 / 4 \\
\text { reddish yellow }\end{array}$ & $\begin{array}{l}\text { Granular to } \\
\text { dense } \\
\text { massive }\end{array}$ & $\begin{array}{l}\text { shells dark grey to black, diatoms and } \\
\text { quartz unaltered, calcite, clay altered, } \\
\text { portlandite }\end{array}$ & $\begin{array}{l}\text { many dark red spots } \\
\text { and some orange red } \\
\text { staining }\end{array}$ & $\begin{array}{l}\text { Calcite depletion zones visible, beginning } \\
\text { hematite formation, destruction of } \\
\text { magnetite/maghemite, } \\
\text { no Kaolinite }\end{array}$ \\
\hline $800^{\circ} \mathrm{C}$ & $\begin{array}{l}7.5 \mathrm{YR} 7 / 4-6 / 4 \\
\text { reddish yellow }\end{array}$ & $\begin{array}{l}\text { Dense } \\
\text { massive, } \\
\text { locally } \\
\text { granular }\end{array}$ & $\begin{array}{l}\text { Very few diatoms and few brown to } \\
\text { black colored shells observed, quartz } \\
\text { grains unaltered, portlandite }\end{array}$ & $\begin{array}{l}\text { many dark red spots } \\
\text { and some orange red } \\
\text { staining }\end{array}$ & $\begin{array}{l}\text { Calcite dissolved, increasing hematite } \\
\text { formation, destruction of } \\
\text { magnetite/maghemite continues, no Kaolinite }\end{array}$ \\
\hline $900^{\circ} \mathrm{C}$ & $\begin{array}{l}10 Y R 7 / 2 \text { light } \\
\text { gray }\end{array}$ & $\begin{array}{l}\text { Dense } \\
\text { massive, } \\
\text { locally } \\
\text { granular }\end{array}$ & $\begin{array}{l}\text { Very few diatoms and brown shells, } \\
\text { quartz grains unaltered, portlandite }\end{array}$ & $\begin{array}{l}\text { many dark red spots } \\
\text { and some orange red } \\
\text { staining }\end{array}$ & $\begin{array}{l}\text { Hematite present } \\
\text { no Kaolinite }\end{array}$ \\
\hline $1000^{\circ} \mathrm{C}$ & $\begin{array}{l}10 \mathrm{YR} 7 / 2-7 / 3 \\
\text { light gray to very } \\
\text { pale brown }\end{array}$ & $\begin{array}{l}\text { Dense } \\
\text { massive }\end{array}$ & $\begin{array}{l}\text { Very few diatoms and no shells } \\
\text { observed, quartz grains unaltered, } \\
\text { portlandite }\end{array}$ & $\begin{array}{l}\text { many dark red spots } \\
\text { and some orange red } \\
\text { staining }\end{array}$ & $\begin{array}{l}\text { Transformation of all Fe-bearing phases to } \\
\text { magnetite/maghemite, no Kaolinite }\end{array}$ \\
\hline $1100^{\circ} \mathrm{C}$ & $\begin{array}{l}10 \mathrm{YR} 7 / 2 \text { light } \\
\text { gray }\end{array}$ & $\begin{array}{l}\text { Granular to } \\
\text { massive }\end{array}$ & $\begin{array}{l}\text { No diatoms observed neither shells, } \\
\text { quartz grains unaltered, portlandite }\end{array}$ & $\begin{array}{l}\text { Locally dark red } \\
\text { spots }\end{array}$ & $\begin{array}{l}\text { Magnetite/Maghemite } \\
\text { no Kaolinite }\end{array}$ \\
\hline
\end{tabular}

${ }^{a}$ The sediment samples exposed to heating show a range of reactions (charring of plant tissue, color change of shell fragments, formation of portlandite, hematite, and magnetite, calcite depletion, local red staining) at the different temperature intervals, which was not replicated in the samples from the purported hearths. 